\title{
Anthropocene-Bio-geography need reverse Gearing in India: Beyond Domestication and Farming
}

\author{
Siba Prasad Mishra ${ }^{\#^{*}}$ and Durga Prasad Mishra^ \\ \#Centurion University of Technology and Management, Jatni, Bhubaneswar, Odisha, India \\ ${ }^{\wedge}$ Ganesh Bhawan, Old Sadar Thana lane, Puri Town, Puri, Odisha, India
}

Received 01 Sept 2018, Accepted 02 Nov 2018, Available online 03 Nov, Vol.8, No.6 (Nov/Dec 2018)

\begin{abstract}
The plate boundaries are the limits of the faunal biodiversity. The species can be endemic, converging or invasive. International Union for Conservation of Nature and Zoological Survey of India are the agencies record and make an action plan to preserve extant/extinct and endangered species. India has $2.4 \%$ of the landmass of the globe but accommodating about 7-8\% of the total species of the world so a rich biodiversity nation. The country lies at the confluence of the Central zone of Africa, Europe and Malaya region, the biota therefore includes African, European, Eurasian and Mediterranean geographical areas, India has a unique assemblage of flora, fauna, avifauna and aquafauna along with some endemic species, that contributes to the richness of the nation. India's biodiversity population changes are influenced by climate, temperature, altitude, invasive alien species, topography, moisture, CO2, light, nutrients, water quality, ambient air, habitation, and above all the anthropogenic activities for their growth, survival, or reproduction. Present study envisages preparation of an updated bio-geographical status of the species, statistical analysis of the biota those are endangered and threatened and causes for such defaunation and defloration. Though preservation action plans have been enhanced in India through biodiversity reserves yet it is observed that the largely under-explored sector is algae, protists, fungi, microbes. The biodiversity in the marine sector is given less importance for conservation in India.
\end{abstract}

Keywords: Biodiversity, sanctuaries, species, geo-biography, Anthropocene, bio-reserves

\section{Introduction}

The assortment of life in all systems, levels, is a consolidation of adjoining genetic species and ecosystem diversity called the bio-diversity. Biogeography is the study of the extensive distribution of species that investigates the changes in dispersal patterns occurred geospatially along with the reasons for evolution and natural selection of flora and fauna. The biodiversity hubs were natural and found the hilly areas, deserts, coasts, islands, and deep seas during the Holocene epoch. The Homosapiens disturbed the natural distribution and settled in the river deltas after domesticating wild animals and utilizing them for agriculture during the Holocene epoch. The geology, topography, climatology, geomorphology, and meteorology of an area govern its geo-biography and ecology.

The study aims at evaluating the present status of various species inclusive endemic, endangered, vulnerable species with their biodiversity, significance and migratory activities in India and across the globe.

*Corresponding author Dr Siba Prasad Mishra (ORCID ID: 00000000-0000-0000; Mobile: 919438668332) is working as Associate Professor and Dr. Durga Prasad Mishra Old Sadara Thana lane, Puri, Odisha, DOI: https://doi.org/10.14741/ijcet/v.8.6.1
The study focuses on the geospatial design of biodiversity and the species under threat and the actions initiated for their conservations. The study also aims at identifying the invasive species and their probable impact on aboriginal flora and fauna in India.

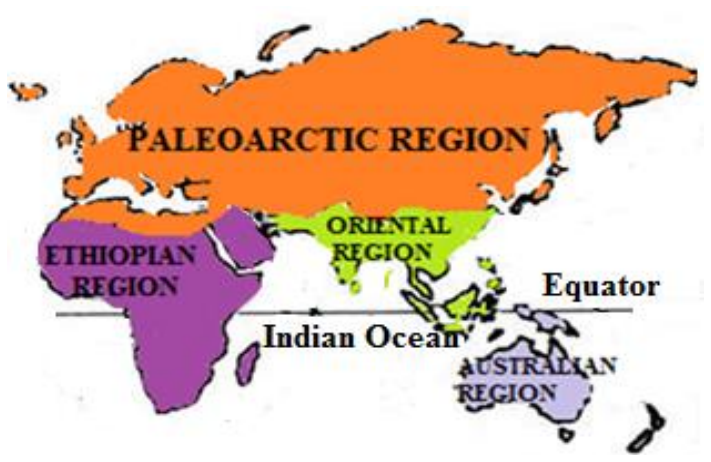

Fig 1: The Biodiversity releams in/around India (Google)

\section{Literature review}

The earth's terrestrial zoogeographical realms were initially delineated by Sclater (1858), further by 
Wallace (1876). Wegener 1915 \& 1929 reported that the climate along the same latitude is roughly identical and same types of species occupy similar regions along a continent, During LGM period the land mass Beringia became ice-free during the last glacial epoch ( little ice age), 15000 - 6000 years BP there was shift towards hot climate and hence the biodiversity https://www2.usgs.gov/climate_landuse/glaciers/glac iers_sea_level.asp. A large number of species became extinct and the migration of many vertebrates especially mammals occurred between North America and Eurasia. Out of 300 ethnic people's community Teledo (2017) of the globe, 150 million live in Asia whereas 68millions in India. India has 227 ethnic groups including 573 tribal groups. They are derived from six racial stocks namely - Negroid, ProtoAustraloid, Mongoloid, Mediterranean, West Breachy and Nordic exists in different part of the country (Pushpgandhan) Rai et al, (2003). The population size of vertebrates (amphibians) are an indicator of ecosystem health as they are sensitive to variations in their environment Welsh et. al., (1998); Malhotra et. al,, (1999). Sheridan et al., (2003); MOEF Report (2010) has reported that the biodiversity of WGB hills is under endemism which contains about one-third of floral species and a hotspot for flora and fauna. The species of WGB hills comprises of 8000 plant class (4780 and endemic 45\%), Vertebrates (1073 and endemic 33\%), Aves species (528 and $7.5 \%$ endemic), reptiles (259 and $62 \%$ endemic), amphibians (116 and 80\% endemic) and mammals (140 and $27 \%$ endemic) as per Envis letter -21/2010 MOEF. Vivero et. al., 2005 reported that Ethiopia had 8000 plant species $(24 \%$ endemic). There are four biodiversity amphitheaters such as Peninsular (endemic biodiversity), IndoMalayan, Palearctic and Ethiopian-Mediterranean amphitheater Mani et al 1974. Animals have a particular distribution in a definite area having specific geographic, ecologic and climatic distinction. The plate boundaries are the limits of the faunal biodiversity (Wallace line). The agreed recent catalog of land masses into different bio-geographic regions and biodiversity are based on Darlington (1957), L. Sclater (1858), Wallace (1876).

\section{Methods and methodology}

Literature Studies reveal that about 5 million to 10 million species live in the globe but 1.73 million species are recorded and the rest needs to be explored and recorded to get a clear picture of Biodiversity and to conduct any realistic studies. India has a land mass of area 3,287,469 Km2 (World 510,065,284.km2) consisting of southern tropical forests and western deserts, northern snow areas, islands and coastline of 7,516.6 km. India has 94500 plants and 100693 animals with 320 types of domesticated wild crops have been cataloged. It is very less compared to available species. The more scientific study is needed in this regard (IUCN 2018). Mishra S. P. 2018. India has
4 mega centers and 26 micrometers but some micro centers and geo-biological networks are yet to be explored and recorded.

The largely under-explored sector is algae, protists, fungi, microbes. The ocean biologists have cataloged only 15042 marine taxa's in Indian marine ecosystem, much less than the world's marine species strata. ( $\sim 2.2$ million), Mora et al (2011)[15]The biodiversity is important for its consumptive, productive, social, ethical, aesthetic, and health values. The numerical values of species statistics are increasing year to year. All estimated 1737248 species are not cataloged. Only 93577 numbers of species have been evaluated by IUCN until 2018. So any speculation about defaunation and defloration activities of the all the taxa shall be misleading.

The updated statistics of domesticated animals used for food generation, geo-biography, zoogeography and plant biodiversity conservation are reported in the present text. The IUCN red list 2018 forms the basis for reporting the rate of defloration and defaunation of species. The increased protective measures taken by the Government for the conservation of the species through bio-reserves, sanctuaries, marine ecosystem reserves is updated from different sources like browsing, visiting sites and old literature.

\subsection{Biodiversity Levels and indices}

Biodiversity has three levels of hierarchy such as genetic, species and community\& ecosystem.. Genetic diversity is the variation of genes within species, species diversity is the variation of species within a zone and the community of ecosystem biodiversity is the level of community and ecosystem. The community diversity has three prospective $\alpha$ diversity, $\beta$ diversity and $\gamma$ diversity. $\alpha$ diversity is the biodiversity within a particular area, community and ecosystem usually measured by species richness and evenness by counting the distinct group of organisms, $\beta$ diversity is a measure of inter-community biodiversity representing the rate of species turn over per unit change in habitat. $\gamma$ diversity measures the overall diversity for the different ecosystem and represents the total species richness over a large area. The relation between $\boldsymbol{\gamma}$ (biodiversity indices) $\boldsymbol{\alpha} \boldsymbol{\alpha}+\boldsymbol{\beta}+\mathbf{Q}$ where, $Q=$ Total number of habitats or communities, $\alpha$ $=$ Average value of $\alpha$ diversities and $\beta=$ Average value of $\beta$ diversities $\mathbf{O R} \boldsymbol{\gamma}=\mathbf{S}_{\mathbf{1}}+\mathbf{S}_{\mathbf{2}}-\mathbf{C}$ where $S_{1}$ is the total numbers of species recorded in the first community, $S_{2}$ is the total number of species in the $2^{\text {nd }}$ community and $\mathrm{C}$ is the common species in the $1^{\text {st }}$ and the $2^{\text {nd }}$ community https://www.slideshare.net/arzoosahni/ eves-biodiversity-notes. However Simpsons's diversity index $\left(\mathbf{D}=\sum\left(\frac{n}{N}\right)^{2}\right.$ or $D=\sum \frac{n(n-1)}{N(N-!)}$ here $\mathrm{n}=$ the population of individuals like individual species, $\mathrm{N}=$ the population of organisms of all species Where D ranges from 0 to 1 . Shannon diversity index $\left(H_{s}\right)=-$ $\sum_{i=1}^{s} P_{i} *\left(\ln P_{i}\right)$ where $\mathrm{P}_{\mathrm{i}}$ is the proportion of individuals found in the ith species in comparison between the the the two sites and the fit value should 
lie between 1.5 to 3.5. The Brillouin index which emphasizes the richness of species population is given by $H_{S}=\left(\frac{\ln N !-\sum \ln n !}{N}\right)$ where $\mathrm{n}=$ the population of individuals like individual species, $\mathrm{N}=$ the population of organisms of all species $n=$ the population of individuals like individual species, $\mathrm{N}=$ the population of organisms of all species. The bio-geographic zones of India is ironic due to the abundance in species of flora and fauna and being ranked 8th and biodiversity Simpsons index is 0.46 (MONGABAY).

\subsubsection{Uses of the Biodiversity}

The Holocene taught us domestication of wild animals/plants and dogged agriculture for human services. About $90 \%$ of foodstuffs obtained from the bio-system. The biodiversity gives us protection from Water Resources, other carnivores, Invasive alien species (IAS), soil toxicity, erosion, nutrient storage and cycling, degradation of waste, pollution regulation, climate combat, biological productivity, carbon sequestration, pest, disease-causing species, and maintain soil fertility. The biodiversity of the ecosystem provides the food, drugs, fiber, fossil fuel and firewood and above all oxygen to breath. Modern studies on genes have helped us to develop healthier medicines, cosmetics, and many industrial products. About 80000 plants are used as food globally and 70$80 \%$ of the people used as medicine of the world.
The drugs in Ayurveda, allopathic, Yunani or homeopathic are the plants or plant extracts, used by about. The lifesaving drugs like Penicillin, Tetracycline are the bright examples. In spite of that activities are leading to the changes in nature and unbalancing carbon footprints in the present epoch.

\subsubsection{Bio-geographical realms}

Holt et al., 2013 have specified the faunal geographical regions of the globe into 11 mega biogeographic zones \& 20 zoogeographical regions. The zoogeographic zones are Nearctic (North America north of Mexico) Panamanian (Central America), Neotropical (South America), Palearctic (Eurasia), Sahara-Arabian (Africa (N) \& Asia (W)), Afro-tropical (Africa, South of Sahara), Madagascan (Madagascar), Oriental (South \& SE Asia), Sino-Japanese(China (part) including Tibet \& Japan), Australian (Australia \& New Zealand), and Oceania (Islands (west) \& central Pacific Ocean). However the transition zones are the significant bridging zone for species world. Five such transition zones identified are Mexican, Sahara-Arabian, Chinese; Indo-Malayan, and South American. Bio-geographers have added two micro bio-geographical regions with fewer species are Andean (Engler, 1882) and the Antarctic. The biogeography spread is classified into six regions. The status is given in Table 1.

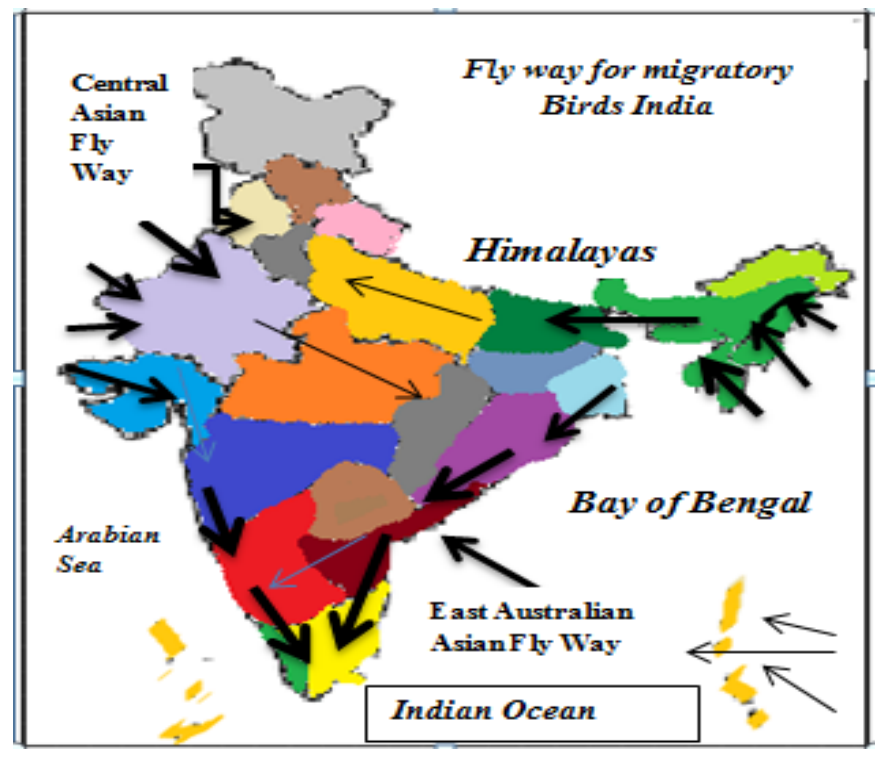

Fig 2: Flyway for migratory birds, India, (source Google)

The mega bio-diversity nations identified in AfroEurasia are India, Brazil, Colombia, Ecuador, Peru, Mexico, Madagascar, Zaire, Australia, China, Indonesia and Malaysia. India has 7-8\% of the total species of the globe and designated as a megadiversity country that is one among the fourth Asian states. India is neighbor to Africa, Europe and Indo-Malaysia region. Unique Ethiopia's (Africa) biodiversity comprises of species more than 6,000 plants, 277 mammals, and above 800 species of Aves congruent to India which is also influenced by its neighboring biodiversity realms (Ethiopian, Paleo-arctic and Indo Malayan).

The migration of flora and fauna is a continuous cyclic process and geospatial. The Himalayan region is a part to the Palearctic region whereas NE Himalayas is a part to the Oriental realm and the deserts of Gujarat are part of Ethiopian realm. 
Table 1: Global Zoogeography, classification, continental distribution and faunal specialty

\begin{tabular}{|c|c|c|c|c|c|}
\hline \# & $\begin{array}{l}\text { Realm/ } \\
\text { landmass }\end{array}$ & $\begin{array}{l}\text { Realm name/ faunal } \\
\text { region }\end{array}$ & Continent & Areas/Countries & Faunal forte \\
\hline 1 & \multirow{2}{*}{$\begin{array}{c}\text { Holarctic } \\
\text { (MEGAGEA) } \\
\text { Sclater 1858, or } \\
\text { Arctogaea } \\
\text { Shukla } \text { et al } 2006\end{array}$} & $\begin{array}{c}\text { Palearctic } \\
\text { Families-42 } \\
\text { Endemic-0 }\end{array}$ & $\begin{array}{l}\text { Temp. Eurasia } \\
\text { (except South \& } \\
\text { SE Asia) }\end{array}$ & $\begin{array}{l}\text { Europe, Russia, } \\
\text { Mediterranean }\end{array}$ & $\begin{array}{c}\text { Rodents, ox's, sheep, goat, deer, } \\
\text { antelope, bear, Necturus \& } \\
\text { Siren }\end{array}$ \\
\hline 2 & & $\begin{array}{c}\text { Nearctic } \\
\text { Families-37 } \\
\text { Endemic-2 }\end{array}$ & $\begin{array}{l}\text { N. America north } \\
\text { of Mexico }\end{array}$ & North America, Mexico, & $\begin{array}{l}\text { American opossum, raccoons, } \\
\text { rodents, iguanas \& rattlesnakes }\end{array}$ \\
\hline 3 & $\begin{array}{c}\text { Holarctic } \\
\text { (NEOGEA) } \\
\text { Rapoport, } 1968\end{array}$ & $\begin{array}{c}\text { Neotropic } \\
\text { Families-50 } \\
\text { Endemic-19 }\end{array}$ & $\begin{array}{l}\text { Central \& South } \\
\text { America }\end{array}$ & $\begin{array}{l}\text { South America, tropical } \\
\text { Mexico and Caribbean } \\
\text { Islands }\end{array}$ & $\begin{array}{l}\text { Rheas, alligators tapirs, sloth, } \\
\text { prehensile-tailed monkey, } \\
\text { vampire bats, }\end{array}$ \\
\hline 4 & $\begin{array}{c}\text { Ethiopian } \\
\text { (MEGAGEA) Sclater } \\
1858,\end{array}$ & $\begin{array}{c}\text { Ethiopian } \\
\text { Families-52 } \\
\text { Endemic-18 } \\
\end{array}$ & $\begin{array}{c}\text { Sub-Saharan } \\
\text { Africa \& SW } \\
\text { Arabia } \\
\end{array}$ & Africa south of Sahara & $\begin{array}{l}\text { giraffe, lion, hippopotamus, } \\
\text { elephant, rhinoceros, }\end{array}$ \\
\hline 5 & $\begin{array}{c}\text { Oriental } \\
\text { (MEGAGEA) } \\
\text { Wallace } 1876\end{array}$ & $\begin{array}{l}\text { Oriental } \\
\text { Families-50 } \\
\text { Endemic-4 }\end{array}$ & $\begin{array}{l}\text { South \& South- } \\
\text { east Asia }\end{array}$ & $\begin{array}{l}\text { Tropical Asia (S), Pakistan, } \\
\text { India Myanmar, S. China, SE } \\
\text { Asia, Indonesian } \\
\text { archipelago (W) }\end{array}$ & $\begin{array}{c}\text { Tarsiers, orangutan, Indian } \\
\text { elephant, rhinoceros, flying fox. } \\
\text { Peacock, Crocodiles }\end{array}$ \\
\hline 6 & $\begin{array}{c}\text { Australian (Oceania) } \\
\text { (NOTOGEA) Engler, } \\
1899\end{array}$ & $\begin{array}{c}\text { Australian } \\
\text { Families-28 } \\
\text { Endemic-17 }\end{array}$ & Australia & $\begin{array}{c}\text { Australia, Fiji, Tuvalu } \\
\text { Kiribati, New Zealand, } \\
\text { Tasmania, New Guinea and }\end{array}$ & $\begin{array}{c}\text { Monotreme spiny anteaters, } \\
\text { marsupials, Sphenodon } \\
\text { lungfish, }\end{array}$ \\
\hline
\end{tabular}

\subsubsection{AVES \& Ticks Migration (Afro Eurasia)}

As per the Agreement on the Conservation of AfricanEurasian Migratory Waterbirds (AEWA), there are 254 species of aves and ticks in Afro-Eurasia.. They cross international barriers by migrations to suitable sites to support their food, climate, reproduction, hatching, breeding, and for better quality habitation. The CMS MOU on the Conservation of Migratory Birds of Prey in Africa and Eurasia (Raptors MOU) has reported 93 species of birds of prey and owls found to migrate within 132 states of Africa, Europe and Asia. The migration may be seasonal, partial, reverse, moult, irruptive, dispersion and cold weather. India falls under the central Asia migration zone of AfroEurasia, East Asia-Australasia Flyway, and one among the eight water birds flyways. But epoch of Anthropocene claims migratory birds do not know and obey any border Fig 2.

\section{Biogeography of India}

Table 2: The area, Bio-geography of the mega/micro centers in India (http://www. indiaenvironment portal.org.in/files/file, http://www.Cpreec .org/pub book-ecozone.htm, https://www.cbd.int/doc/world/in/innr-05-en.\& http://www.indiaenvironmentportal.org.in

\begin{tabular}{|c|c|c|c|c|c|c|}
\hline \# & $\begin{array}{l}\text { Biogeograp } \\
\text { hic zone }\end{array}$ & Geographical areas & Area & climate & Hills & Threat to Bio-diversity \\
\hline & & Mega Centers & $\mathrm{Km}^{2}$ & & Mountains & Causes \\
\hline 1 & $\begin{array}{c}\text { Trans- } \\
\text { Himalayas }\end{array}$ & $\begin{array}{l}\text { Ladakh, Tibetan Plat. } \\
\text { Siachin, Leh, Srinagar, } \\
\text { Lahul-Spiti H.P.) }\end{array}$ & 174225 & $\begin{array}{l}\text { Cold/Sub- } \\
\text { Alpine/Alpine } \\
\text { Forest }\end{array}$ & $\begin{array}{l}\text { Zaskar, Ladakh, } \\
\text { the Kailas,, the } \\
\text { Karakoram }\end{array}$ & $\begin{array}{l}\text { Anthropogenic, climate } \\
\text { change(CC) tourism, , } \\
\text { deforesting, NTFS,, } \\
\text { human-animal fight, }\end{array}$ \\
\hline 2 & $\begin{array}{c}\text { Eastern } \\
\text { Himalayas }\end{array}$ & $\begin{array}{l}\text { Assam \& Aru nachalPr. } \\
\text { Sikkim, Cherrapunji, } \\
\text { Imphal, Shillong }\end{array}$ & 83000 & $\begin{array}{l}\text { Cold/moist, heavy } \\
\text { r/f, Moist Temp, } \\
\text { Subgroup- Pine } \\
\text { Forest } \\
\end{array}$ & $\begin{array}{l}\text { The Patkai-Bum } \\
\text { Hill, Garo-Khasi- } \\
\text { Jaintia Hills, } \\
\text { (Mizo Hill) }\end{array}$ & $\begin{array}{c}\text { CC, deforestation, IAS, } \\
\text { NTFPs, fire, LU } \\
\text { urbanization, mining, } \\
\text { tourism. (CC), NTFPs, }\end{array}$ \\
\hline 3 & $\begin{array}{l}\text { Western } \\
\text { ghat Hills }\end{array}$ & $\begin{array}{c}\text { Malabar plains, Western } \\
\text { Ghats }\end{array}$ & 99300 & $\begin{array}{c}\text { Tropical/monsoon } \\
\text { climate, Tropical } \\
\text { Wet Evergreen } \\
\text { Forest }\end{array}$ & $\begin{array}{l}\text { Agasthyamalai, } \\
\text { Palini, Nilgiri hills }\end{array}$ & $\begin{array}{l}\text { IAS, exotic mining, } \\
\text { disease plantations, } \\
\text { intrusion, exploitation } \\
\text { NTFPs, co-extinction } \\
\text { poaching, fire, , CC. }\end{array}$ \\
\hline 4 & Deserts & $\begin{array}{l}\text { Thar, Great Rann of } \\
\text { Kutch, \& Snow deserts }\end{array}$ & $\begin{array}{c}213672 \& \\
7770\end{array}$ & $\begin{array}{l}\text { Dry, Tropical Thorn } \\
\text { Forest, cold climate }\end{array}$ & $\begin{array}{c}\text { Aravalli hills, Pin } \\
\text { Valley, } \\
\text { Chandratal }\end{array}$ & $\begin{array}{l}\text { IAS, LU change, livestock } \\
\text { killing, grassland } \\
\text { degradation, }\end{array}$ \\
\hline
\end{tabular}

India is rich in biodiversity due to its biogeographic location at the triple point of Palaearctic, Afro-Tropical and Oriental region. Biodiversity starts from the genetic level such as genetic variability of species to the biota in a definite expanse of its ecosystem of the neighboring region. Species diversity can be sensed in a biodiversity hotspot area whereas ecosystem diversity is the level of organization in an ecosystem. India stands as the 10th position among floral rich nations of the globe. India, part of the Oriental realm, is small in area and comprises of mammals (20 families) common to Palearctic, Ethiopian region but different from Australian. About 120 families of angiosperms are common to Neotropical and Australian indicating India is a country having diverse biodiversity https://pdfs.semantic scholar.org /presentation /ab10/435. India belongs to three regions of the geobiogeographic system. About $\approx 90 \%$ of the subcontinent belongs to the Oriental region. 


\begin{tabular}{|c|c|c|c|c|c|c|}
\hline & & Micro Centers & & & & \\
\hline 1 & $\begin{array}{c}\text { NW } \\
\text { Himalaya }\end{array}$ & $\begin{array}{c}\text { Himachal Pradesh, J\&K, } \\
\text { Uttarakhand }\end{array}$ & 69033 & $\begin{array}{l}\text { Himalayan Moist } \\
\text { Temperate Forest }\end{array}$ & $\begin{array}{c}\text { Aravali, Himadri, } \\
\text { Himachal, Siwalik } \\
\text { Hills }\end{array}$ & $\begin{array}{c}\text { CC, deforestation, fire, } \\
\text { invasive species, NTFPs, } \\
\text { tourism. LU change, } \\
\text { urbanization, }\end{array}$ \\
\hline 2 & $\begin{array}{l}\text { Western } \\
\text { Himalaya }\end{array}$ & $\begin{array}{c}\text { Karakoram, Zanskar, } \\
\text { Pirpanjal, Siwalik Hills, } \\
\text { Kumaon Himalaya }\end{array}$ & 720000 & $\begin{array}{l}\text { Himalayan Dry } \\
\text { Temp. Forest }\end{array}$ & $\begin{array}{c}\text { Tarai, Riparian } \\
\text { Forests, } \\
\text { Grasslands }\end{array}$ & $\begin{array}{l}\text { CC, deforestation, LU/LC } \\
\text { change, IAS NTFPs, } \\
\text { Poaching, fire, sprawl, } \\
\text { mining, tourism. }\end{array}$ \\
\hline 3 & $\begin{array}{c}\text { Cent. } \\
\text { Himalayas }\end{array}$ & $\begin{array}{c}\text { Uttarakhand, Sikkim \& } \\
\text { Nepal Himalaya }\end{array}$ & 83000 & $\begin{array}{c}\text { subtropical } \\
\text { broadleaf/mixed } \\
\text { conifer/conifer } \\
\text { forests alpine } \\
\text { meadows } \\
\end{array}$ & $\begin{array}{c}\text { Kathmandu, } \\
\text { Pokhara valleys, } \\
\text { Tarai, Siwalik } \\
\text { range, } \\
\text { Nanaga/Namcha }\end{array}$ & $\begin{array}{l}\text { CC, deforestation, LU } \\
\text { change, tourism mining } \\
\text { IAS, fire, Exploiting } \\
\text { NTFPs, urbanization }\end{array}$ \\
\hline 4 & $\begin{array}{c}\text { Gangetic } \\
\text { Plains, }\left(20^{0}\right. \\
\text { N Lat) }\end{array}$ & $\begin{array}{c}\text { Uttarakhand, UP, Bihar, } \\
\text { Assam(W) }\end{array}$ & 107600 & $\begin{array}{c}\text { Moderate } \\
\text { temperature / } \\
\text { rainfall }\end{array}$ & $\begin{array}{l}\text { Floodplains, } \\
\text { Aravalli-Bindhya } \\
\text { \& Satpura hills }\end{array}$ & $\begin{array}{c}\text { CC, mining, } \\
\text { Deforestation, loss of } \\
\text { grassland IAS, } \\
\text { anthropogenic act, LU/L } \\
\text { change, pollution }\end{array}$ \\
\hline 5 & \multirow{3}{*}{$\begin{array}{l}\text { Islands arcs } \\
\text { of India }\end{array}$} & Andaman Islands & 6575 & $\begin{array}{c}\text { Tropical/moderated } \\
\text { by sea breezes }\end{array}$ & Sunda Lands & \multirow{3}{*}{$\begin{array}{c}\text { Habitat loss/ Hunting, } \\
\text { fragmentation, Species } \\
\text { Exploitation Exotic } \\
\text { species, Poaching } \\
\text { Pollution, Pests, } \\
\text { \&Predators, Global } \\
\text { warming, Extreme, CC }\end{array}$} \\
\hline 6 & & $\begin{array}{l}\text { Great Nicobar group of } \\
\text { Islands }\end{array}$ & 3287 & $\begin{array}{c}\text { Tropical/moderated } \\
\text { by sea breezes }\end{array}$ & Sunda lands & \\
\hline 7 & & Lakshadweep islands, & 3110 & $\begin{array}{c}\text { Tropical/moderated } \\
\text { by sea breezes }\end{array}$ & Coastal Lands & \\
\hline 8 & $\begin{array}{l}\text { Semi-Arid } \\
\text { Zone: } \\
\end{array}$ & $\begin{array}{c}\text { Punjab plains, Gujarat } \\
\text { Rajput Ana, }\end{array}$ & 287000 & $\begin{array}{c}\text { Rainshadow of } \\
\text { WGB, grasslands }\end{array}$ & $\begin{array}{r}\text { Satpura, Throny\& } \\
\text { deciduous Forest }\end{array}$ & \multirow{2}{*}{$\begin{array}{c}\text { Habitat loss/ } \\
\text { fragmenting, IAS, } \\
\text { exploitation of species, } \\
\text { CC, and pollution, LU } \\
\text { change. IAS, }\end{array}$} \\
\hline 9 & $\begin{array}{l}\text { Deccan } \\
\text { Peninsula } \\
\text { Zone }\end{array}$ & $\begin{array}{l}\text { Cent. high lands, } \\
\text { Chhotnagpur Hills, } \\
\text { Deccan South }\end{array}$ & 378000 & $\begin{array}{l}\text { Tropical uneven } \\
\text { climate/ dry } \\
\text { evergreen } \\
\text { deciduous }\end{array}$ & $\begin{array}{l}\text { Nallamalai, Sunki, } \\
\text { Deomali, Sukma, } \\
\text { hill ranges }\end{array}$ & \\
\hline 10 & $\begin{array}{l}\text { Coastal } \\
\text { Zones }\end{array}$ & East coast & 6500 & $\begin{array}{l}\text { Tropical, deciduous } \\
\text { forest, \& mangroves }\end{array}$ & $\begin{array}{l}\text { Estuarine biota } \\
\text { EGB hills, lagoon } \\
\text { Chilika } \\
\end{array}$ & \multirow{2}{*}{$\begin{array}{c}\text { Habitat loss, Hunting, } \\
\text { Exploitation Species, } \\
\text { Fragmentation, IAS, } \\
\text { Exotic Species, Pollution, } \\
\text { Pests, Predators, } \\
\text { Calamities, CC, Global } \\
\text { warming }\end{array}$} \\
\hline 11 & $\begin{array}{l}\text { (Marine } \\
\text { influenced- } \\
10440 \mathrm{Km})\end{array}$ & West coast & 6500 & $\begin{array}{c}\text { WGB Hills, } \\
\text { Harishchandra and } \\
\text { Satmala range }\end{array}$ & $\begin{array}{l}\text { lagoons, Malabar, } \\
\text { Konkani }\end{array}$ & \\
\hline
\end{tabular}

The Thar Desert is included recently in mega-biospheres of India which is populous (17.44 million) and has vast livestock (23.33 million) in comparison to other deserts of the world Khan et al, (2003). http://www.bsienvis.nic.in/Database/Biodiversity-Hotspots-in-India_20500.aspx

A part of the west of $J \& K$ to Rajasthan is lying in the border of the Sahara-Arabian biodiversity region. The major part of Himalayan ranges belongs to the SinoJapanese region i.e. Palearctic region. The major and micro biodiversity centers are in Table 2 .

\subsubsection{Geological Evolution behind Geo-biodiversity India}

Evidence of the geological evolution of species is ascertained from paleontology (fossil records), Phylogeny (systematics) and biotic interchange of the area. The geologic backgrounds on the diverse biodiversity of India are interrelated to the chronological geological phenomena's (a)Rift, break up and shifting of Gondwana land of Indian plate in preCambrian age (b) Drifting and shifting of the Indian plate from Antarctica (c) Prolonged volcanic eruption Deccan and Chhotanagpur plateau (d) Protracted collision of the Indian plate with the Asian landmass (e) 22Mounting of the Himalayas ranges from west to east with Tibetan plateau (f) WGB hills formation due to down-warping of Konkani low lands into Arabian Sea (g) Meteorological extremes, Tsunamis and climatic anomalies (h) Estuarine, lagoon and island biodiversity (k) Pleistocene warm periods and Ice ages (l) Present Anthropogenic pressure in the Anthropocene epoch (m) Disjunct distribution species in India. The major three biogeographic distribution of species (small or large) can be cosmopolitan (globally distributed), endemic (aboriginal locally disseminated) and Holarctic disjunct (Geospatially and geographically spread). Biogeographic realms created by Wallace A R. (1876) based upon, identical or congruent characteristic within the endemic species of an area those are convergent under similar adaptations. Different theories were put forth by different authors regarding the distribution of species based on dispersal, and vicariance (splitting). The distribution of species in India mostly fall under the disjunctive distribution of species Darwin C. (1859), Ali (1949), Hora (1949, Ripley 1949, Karanth 2003, Mani, 1974,.Different theories were framed for the distribution of flora and fauna and their migrations Shukla R. P., 2006 are Deccan Traps Theory (NorthSouth intermix through barriers Satpura hills Hora et al 1949, Himalayan glaciation theory Medlicott et al 1849, late Pleistocene glaciation compelled species to migrate to tropics), Continental-drift theory (Discontinuity of migration due to climate changes, 
Alfred Wegener 1966, The equilibrium theory of island biogeography Mac-Arthur and Wilson 1963, 1967, island species migration depends on population and proximity to land mass) and land breeze theory. The pertaining dispersal and migration routes are Satpura Hills range or EGB Hills range to WG Hills range and then to Srilanka. The hypothesis of migration of species has occurred from Australia to India through oceanic paths. Barriers to the migration of the flora and faunal biome are climate, topography, physiography, edaphic, biotic, genetic, reproductive and anthropogenic. The other routes of migration from one biodiversity hotspot area to other are Aravalli hills Abdulali, $\mathrm{H}$. 1949[29], Mani, M.S.,1976, Satpura-Vindhya hills range Hora S. L.,1949, Govardhan Hill in Braj Digler 1952, in Karanth K. P., 2003[32], and EGB Hills range. Beyond the main routes, the secondary intra migration paths are through Aravali Hills range for passage of NW Himalayan species, Darjeeling hills and Garo- Rajmahal (Bindhya) hills range for mid-Himalayan species, Darjeeling- Chittagong hills for east Himalayan species and Mizo Hills to Gandhamardan via Chittagong Hills, Sundarbans. The aqua fauna of India are also migratory and travels thousands of kilometers to reach the Coasts of India and breed and swim away to their native habitation. Kartik Shanker had shown the path migratory turtles in Indian ocean http://www.fao.org /docrep 007/y5750e/y5750 Fig 3. Similarly the the fishes and aqua faune takes some predetermined path and traves through the Indian ocean and bay of Bengal then through Arbian coast and swim to Coasts of Africa Fig 4.

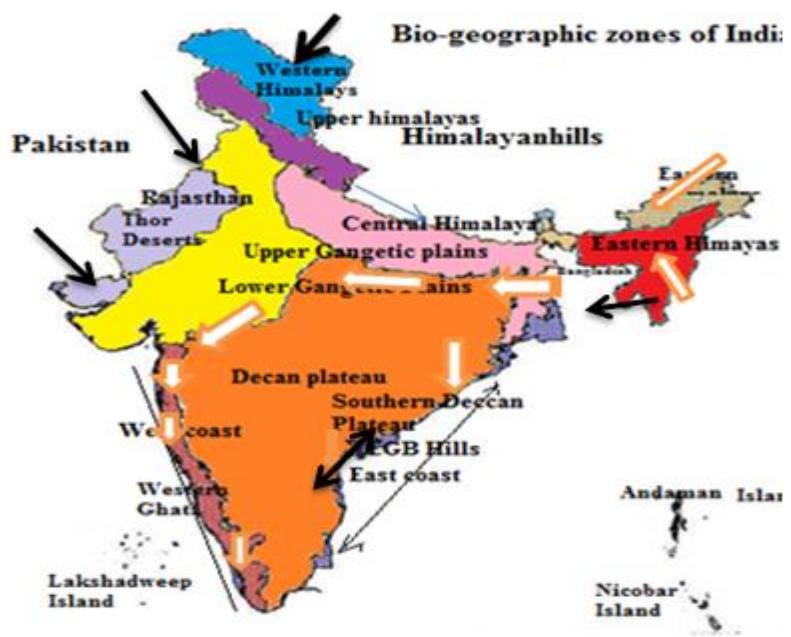

Fig 3: The major migration paths of animals in biogeography map of India, (Source Google)

The exodus act of species can be biotic or abiotic. The biotic factors are genetic homogeneity, mobility, seed dispersal, food scarcity, search for a better partner whereas the abiotic factors are meteorological, geomorphologic, geologic, climatic vagaries, soil-type, floods and topography. The migrant species must have grown genetically under appropriate geomorphological, physiological, biomechanical, behavioral, and life-history characters under suitable climatic condition Fuller et. al., 2005; Hobson, 2008, Holland et. al.,2009. The geographical isolation of species stimulates the evolution of new species through variation, crossbreeding and mutation.

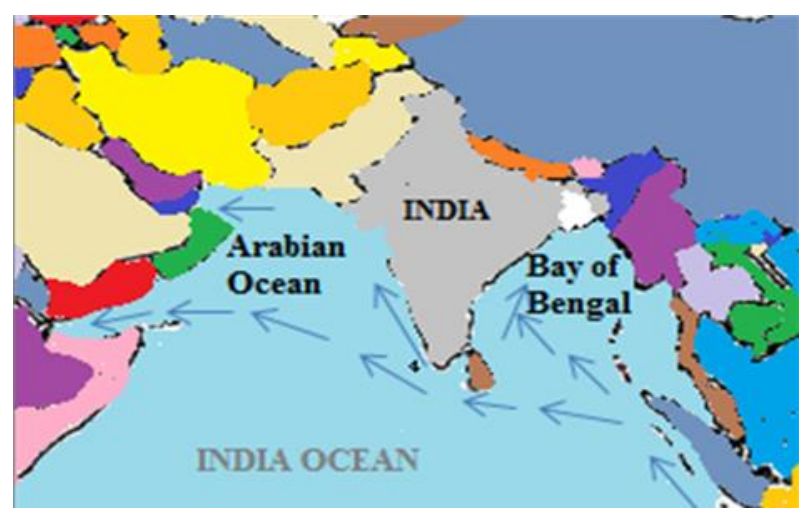

Fig 4: Migratory path of aqua fauna in marine area, India

\subsubsection{Forest India}

Total Land Area of Earth is 510,065,284 sq.km with a forest Cover of 38.7 million sq.km (26\%). About $40 \%$ of global forest land is in South America, Africa, and South Asia. India is in South Asia. There were 16 main types of forest types with 221 subtypes spread in 4.1 MHA of lacustrine areas not including paddy fields and mangroves in India. The ranking of India in the global diversity is 8th against mammals and birds, 5th for reptiles and 15th to 20th for amphibians and angiosperms IUCN - 2018. The country has about 6700 $\mathrm{km} 2$ mangroves area (7\% of the world). The list of land area under forest and tree cover placed India as 10 th rank in the world. India has forest cover of $24.4 \%$, even though it accounts for $2.4 \%$ of the land mass of the globe focusing on India, biodiversity enriched. India has $708273 \mathrm{Km} 2$ of forest which is $21.53 \%$ of the total geographical area of the country FSI, 2011. Considering ISFR data 2009, there were $83471 \mathrm{~km} 2$ of thickly dense forests (crown density >70\%), $320736 \mathrm{~km} 2$ (crown density of 40 to $70 \%$ ) of moderately thick forests exists in India. The remaining $287820 \mathrm{Km} 2$ are open forest having crown density 10 to $40 \%$, existed in India.

India State of Forest Report of MOEFCC (ISFR 2017), reported that overall forest and vegetation spread in the country has added by $8021 \mathrm{~km} 2(6778$ $\mathrm{km} 2$ and tree cover as $1243 \mathrm{~km} 2$ ), which is $1 \%$ increase from 2015. The CO2 absorbing sources, very dense forests have increased by $1 \%$. The present increase in forest cover was in the eastern Himalayan states such as Nagaland, Arunachal Pradesh, Tripura and Meghalaya's having $531 \mathrm{Km} 2,450 \mathrm{Km} 2,190 \mathrm{Km} 2$, $164 \mathrm{Km} 2$ and $116 \mathrm{Km} 2$ rises respectively. http://mospi.nic.in/statistical-year-bookindia/2017/202 
Table 3: Statistics of the Protected Areas in Indian subcontinent updated 2018

\begin{tabular}{|c|c|c|c|c|c|}
\hline \# & Specialties & unit & India & $\%$ of world & Source \\
\hline 1 & Land area & $\mathrm{Km}^{2}$ & 3287469 & 2.21 & Govt. of India[46] \\
\hline 2 & Population 2018 & Million & 1355.3 & 17.74 & Worldometer \\
\hline 3 & Forest cover $2 / 2018$ & $\mathrm{Km}^{2}$ & 708273 & $\begin{array}{l}21.54 \% \text { Ind, } \\
2.4 \% \text { world }\end{array}$ & ISFR-17, W. Bank.-2015 \\
\hline 4 & Forest/tree cover & $\mathrm{Km}^{2}$ & 802088 & $24.39 \%$ of India & ISFR 2017 \\
\hline 5 & Mangrove & $\mathrm{Km}^{2}$ & 4921 & $0.15 \%$ of India & FSI 2017 as per H Times \\
\hline 6 & National parks NP's & $\begin{array}{l}\text { Nos } \\
\mathrm{Km}^{2}\end{array}$ & $\begin{array}{c}104 \\
40501\end{array}$ & $1.23 \%$ of India & http://www.wiienvis.nic.in/Database \\
\hline 7 & WLS's, 2018 & $\begin{array}{l}\text { Nos } \\
\mathrm{Km}^{2} \\
\end{array}$ & $\begin{array}{c}544 \\
118932 \\
\end{array}$ & $3.62 \%$ of India & $\begin{array}{c}\text { http://www.teriin.org/opinion/ protected- } \\
\text { area-network-India }\end{array}$ \\
\hline 8 & PA's 2018 & $\begin{array}{l}\text { Nos } \\
\mathrm{Km}^{2}\end{array}$ & $\begin{array}{c}770 \\
162099 \\
\end{array}$ & $4.93 \%$ of India & http://www.wiienvis.nic.in \\
\hline 9 & $\begin{array}{c}\text { Conservation Reserves } \\
\text { (CRs) }\end{array}$ & $\begin{array}{l}\text { Nos } \\
\mathrm{Km}^{2}\end{array}$ & $\begin{array}{c}77 \\
2594 \\
\end{array}$ & $0.08 \%$ of India & http://knowindia.gov.in \\
\hline 10 & Community Reserves & $\begin{array}{l}\text { Nos } \\
\mathrm{Km}^{2}\end{array}$ & $\begin{array}{c}46 \\
72.6\end{array}$ & $0.002 \%$ of India & $\begin{array}{c}\text { http://www.teriin.org/opinion /protected- } \\
\text { area-network -India }\end{array}$ \\
\hline 11 & Herbarium & Nos & 79 & NA & $\begin{array}{c}\text { http://www.bsienvis.nic.in/Database/Floral } \\
\text { _Statistics_of_India_ }\end{array}$ \\
\hline 11 & Costal (MPA's) & $\begin{array}{l}\text { Nos } \\
\mathrm{Km}^{2} \\
\end{array}$ & $\begin{array}{c}25 \\
8231.5\end{array}$ & $0.0025 \%$ of India & \multirow{2}{*}{$\begin{array}{l}\text { http://natureconservation.in/list-of-marine- } \\
\text { protected-areas-in-india-updated }\end{array}$} \\
\hline 12 & Island MPA's & $\begin{array}{l}\text { Nos } \\
\mathrm{Km}^{2}\end{array}$ & $\begin{array}{c}106 \\
1570 \\
\end{array}$ & $0.0005 \%$ of India & \\
\hline
\end{tabular}

\subsubsection{Biodiversity Protected Areas India}

Global statistics by Deguignet M. et al., 2014 UN reported about 209,429 protected areas (PA's), distributed in 193 countries of the world covering $32,868,673 \mathrm{~km} 2$ and spread in 11 regions such as Africa, Asia, America, Caribbean, Central, Europe, Middle East, North America, Oceania, South America and Southern Oceans. It was 9,214 PA's in 1962 and the area under the PA's were $2,400,000 \mathrm{Km} 2$. The largest being the Marine area, the Oceania, Natural Park of the Coral Sea (France) spread over 1,292,967Km2 followed by Southern Oceans South Georgia and South Sandwich Islands PA's (UK) 1,070,000Km2.

According to UNEP-WCMC (2018), India reports 672 units of protected terrestrial areas covering $182647 \mathrm{~km} 2$ out of $3061193 \mathrm{~km} 2$ of the total land area of India. The protected marine areas of India consisting of $0.17 \%$ cover (3928 km2) is out of $2301226 \mathrm{~km} 2$ total marine area. https://protectedplanet.net/ country/ IN. There are three protected areas as biosphere reserves such as Nanda Devi, Gulf of Mannar and Nicobar islands as the area has recognition, dedication and management, through legal or other operative means, to accomplish the long-term protection of nature with associated ecosystem services and cultural values, IUCN 2008. The details of the protected areas in the Indian subcontinent updated is given Table- 3

\subsubsection{Wildlife sanctuaries}

In the Anthropocene epoch, the conservation of wildlife species like flora, fauna, avifauna and aquafauna became the need of the hour. Hence 498 numbers of sanctuaries have been created to date after the date of commencement of the new epoch from 1945 onwards.

Table 4: Status of major WLS's/ some Biodiversity reserve sites, India (UNEP-WCMC (2018)

\begin{tabular}{|c|c|c|c|c|c|c|c|c|}
\hline \# & Category & No. & $\begin{array}{c}\text { Biodiversity zone } \\
\text { (Name) }\end{array}$ & State & Famous Fauna & $\begin{array}{l}\text { IUCN } \\
\text { Type } \\
\end{array}$ & Area $\mathrm{Km}^{2}$ & Year \\
\hline \multirow[t]{10}{*}{1} & Sanctuaries & 498 & Wild Ass & Gujarat & Wild ass & III & 4954 & 1974 \\
\hline & & & Ranthambore & Gujarat & Tiger & II & 392 & 1957 \\
\hline & & & Periyar & Kerala & Elephant & IV & 427 & 1950 \\
\hline & & & Desert NP & Rajasthan & Camel & II & 3162 & 1980 \\
\hline & $\begin{array}{l}\text { http://www.wiie } \\
\text { nvis.nic.in/Data }\end{array}$ & & $\begin{array}{l}\text { Nagarjunsagar- } \\
\text { SrisailamT.R. }\end{array}$ & AP & Tiger & IV & 3568 & 1978 \\
\hline & & & $\begin{array}{l}\text { Nelapattu Bird } \\
\text { Sanctuary }\end{array}$ & AP & $\begin{array}{c}\text { Flamingo Palearctic } \\
\text { bird }\end{array}$ & $\begin{array}{c}\text { Threate } \\
\text { ned }\end{array}$ & 3568 & 1976 \\
\hline & & & Campbell Bay & Nicobar & $\begin{array}{l}\text { bravura orchids, ferns } \\
\text {,crabs, turtles, }\end{array}$ & IV & 426.2 & 1992 \\
\hline & & & $\begin{array}{l}\text { Gr. Indian Bustard } \\
\text { Sanctuary }\end{array}$ & Maharastra & Indian Bustard & IV & 8496 & 1979 \\
\hline & & & Sathyamangalam & $\mathrm{TN}$ & Tiger & IV & 1412 & 2008 \\
\hline & & & Kutch Desert WLS & Gujarat & & & 7506 & 1986 \\
\hline 2 & Biosphere reserve & 3 & $\begin{array}{c}\text { Nandadevi } \\
\text { Gulf of Mannar } \\
\text { Great Nicobar }\end{array}$ & $\begin{array}{c}\text { UP } \\
\text { TN } \\
\text { A.\&N. }\end{array}$ & $\begin{array}{c}\text { Orchid Asteraceae, } \\
\text { Dugong, Crab eater } \\
\text { monkey }\end{array}$ & $\begin{array}{l}\text { NR } \\
\text { VI } \\
\text { VI } \\
\end{array}$ & $\begin{array}{c}6407 \\
10500 \\
885\end{array}$ & $\begin{array}{l}198819 \\
891989\end{array}$ \\
\hline 3 & Birds reserve & 1 & Nilgiri & Karnataka & & NR & 5520 & 1986 \\
\hline 4 & Closed Area & 1 & Doli & Rajasthan & Black Buck, & NR & 706 & \\
\hline
\end{tabular}


Besides the Bio-geo-graphical reserves there are 50 Tiger Reserves (TR) covering 71,027.10 km2, 16 Elephant Reserves, 26 Ramsar Wetland Sites $(12,119.03 \mathrm{~km} 2)$ for saving the wild large animals. www.environment.gov.au Apart from the above biosphere reserves, India has a number of notable avifauna reserve sites such as Bharatpur Bird Sanctuary (Rajasthan), Nal Sarovar Bird Sanctuary (Gujarat), Ranganthittu Bird Sanctuary, (Karnataka), Nalabana Sanctuary,Chilka Lake (Odisha), Mayani Bird Sanctuary, (Maharashtra), Salim Ali Bird Sanctuary, (Goa), Sultanpur Bird Sanctuary, (Haryana), Kumarakom Bird Sanctuary, (Kerala) and many others. The status of major sanctuaries is in Table 4.

\subsubsection{Biodiversity hot spots}

Biodiversity hotspots are the areas that sustain natural ecosystems those are largely intact and where endemic species linked with the bionetworks are well represented. A biodiversity hotspot area must fulfill the criterion of minimum 1500 vascular endemic plants or $(>0.5 \%$ of the globe) and lost minimum $70 \%$ of its original habitat. According to Conservation International (CI), there are 35 bio-diversity hot spots in the globe including 4 from India. The listed 35 hotspots comprise of Asia Pacific (12 nos), African subcontinent (8 nos), Europe and central Asia (6 nos), South America has (5 nos), and North and Central America (4 nos). The prominent biodiversity hotspots of India are Himalayan belt. The Indo-Burma biodiversity hotspot areas including North-east India (except Assam and Andaman group) and the Sundaland consisting of Nicobar group of Islands. The smallest among biodiversity hotspots is the Western Ghats. At present biodiversity hotspots are susceptible for to threat due to deforestation, habitat loss and fragmentation.

\subsubsection{Biodiversity heritage sites (BHS), India}

BHS sites are distinctive ecologically fragile ecosystems (terrestrial, coastal and inland and marine lacustrine systems) possessing iconic biodiversity involving any one or more of the components such as: rich in wild/domesticated species, high endemism, possessing rare and threatened species, species of evolutionary significance, wild descendants of domestic/cultivated species, possessing historical pre-eminence of fossil beds and significant cultural, ethical or of aesthetic values of cultural diversity having a long history of hominid association with them.

To preserve biodiversity the Indians Authority have listed 23 heritage centers out of which few important conservation spots are Kaziranga National Park \& Manas Wildlife Sanctuary (Assam) Keoladeo National Park (Rajasthan) Sunder bans National Park ( West Bengal) Glory of Allapalli, Gadchiroli, Tonglu BHS, Dhotrey BHS under the Darjeeling Forest Division, Darjeeling, Dialong Village, Tamenglong and Nanda
Devi National Park, Uttaranchal and many others. In March 2017, The Sustainable Action for Climate Resilient Development (SACRED) has designated Majuli, Assam, Indiaas the largest river island of the globe, as a carbon neutral site to fight against climate change and depletion of GHG's and to maintain its ecological culture and legacy.

\subsubsection{Biosphere Reserves in India}

'Man \& Biosphere' (MAB) programme by UNESCO in 1971 has initiated reserving areas of terrestrial, lacustrine and coastal ecosystems to encourage and safeguard the biodiversity along with its support system and ethno-botanical uses. The MAB need immediate preservation, protection and nurturing of its endangered flora and fauna. MAB had identified the first biosphere reserve in 1979 and at present more than 651biosphere reserves and 15 trans-boundary reserves in 120 countries around the globe. Presently, there are 18 biosphere reserves are existing in India comprising area $91272 \mathrm{Km}^{2}$. Convention on Biological Diversity (CBD) had focused on the zoning of core areas of biodiversity, buffer zones for sustainable biodiversity and transition zones. The primary criteria are effective protection and habitat area loss for extension and conservation of nature and the core area should be biogeographically extended to accommodate all trophic levels of the sustainable ecosystem. The other norm is that the core area should have rare and endangered species in various types of soil, differing soil, aboriginal varieties of flora and fauna. India has declared 18 numbers of biodiversity reserves (MOEF) and 10 numbers out of them are included as part to world network programme (UNESCO) http:// natureconservation.in/ list-of-biosphere-reserves-inindia-updated. Status of Biosphere reserves is in Table 5.

The biospheres where the ancient culture preserved by implementation of national policies are Nilgiri (2000), Gulf of Mannar (2001), Sunder bans (2001), Nanda Devi (2004), Nokrek (2009), Pachmarhi (2009), Similipal (2009), Achanakmar-Amarkantak (2012) , Great Nicobar (2013) and Against- yamala (2016).

\subsubsection{Biodiversity and aboriginal Indians}

Aboriginal people spread over India in a land mass area of $329 \mathrm{MHa}$, which harbors 306.686 million species (2809 indigenous groups) and these inhabitants are the architects of their jungle land. The traditional /indigenous groups cover $22 \%$ of total land whose lifestyle sustained with the major biodiversity of the area. Similar indigenous/ethnic tribes are now found in South and North Americas, Africa and Asia. As the son of the soil and as an aboriginal community tapping on ancestral knowledge, they are erudite about conservation of the biodiversity in significant areas and primitive territories. The ethnic community must be protected to survive in their pristine environment rather than modernizing them. 
Table 5: Status of Biosphere reserves under geo-climatic conditions of India

\begin{tabular}{|c|c|c|c|c|c|c|c|}
\hline \# & Name of MAB & $\begin{array}{c}\text { Biogeographic } \\
\text { zone, }\end{array}$ & $\begin{array}{c}\text { Year } \\
\text { declaration }\end{array}$ & $\begin{array}{l}\text { States of } \\
\text { India }\end{array}$ & $\begin{array}{l}\text { Area } \\
\mathrm{Km}^{2}\end{array}$ & $\begin{array}{l}\text { Places (parts of districts } \\
\text { and places) }\end{array}$ & $\begin{array}{c}\text { Major Biota (Endemic } \\
\text { species) }\end{array}$ \\
\hline 1 & Nilgiris & Western Ghats & 1.1 .1986 & $\begin{array}{l}\text { TN, Kerala, } \\
\text { Karnataka }\end{array}$ & 5520 & $\begin{array}{c}\text { Wayanad, Nagarhole } \\
\text { Bandipur, Udumalai, } \\
\text { Milambur, Silent, valley, } \\
\text { Siruvani hills, }\end{array}$ & $\begin{array}{l}\text { Nilgiri Tahr, Lion- } \\
\text { tailed macaque }\end{array}$ \\
\hline 2 & Nanda Devi & $\begin{array}{c}\text { Western } \\
\text { Himalayas } \\
\text { (MAB) }\end{array}$ & 18.1.1988 & Uttarakhand & 5860 & $\begin{array}{c}\text { Chamoli, Pithoragarh } \\
\text { and Almora districts, } \\
\text { Ladak and Nepal }\end{array}$ & $\begin{array}{l}\text { Himalayan Snow } \\
\text { Leopard }\end{array}$ \\
\hline 3 & Nokrek & East Himalayas & 1.9 .1988 & Meghalaya & 820 & $\begin{array}{c}\text { East, West and South } \\
\text { Garo Hill }\end{array}$ & Red Panda \\
\hline 4 & $\begin{array}{l}\text { Gulf of } \\
\text { Mannar }\end{array}$ & Coastal(MAB) & 18.2.1989 & TN & 10500 & Ram swarm, & $\begin{array}{l}\text { Dugong, Corals, } \\
\text { mangroves }\end{array}$ \\
\hline 5 & Sundarbans & Coastal (MAB) & 29.3.1989 & West Bengal & 9630 & $\begin{array}{c}\text { Ganga-Brahmaputra } \\
\text { delta }\end{array}$ & Royal Bengal Tiger \\
\hline 6 & $\begin{array}{l}\text { Nicobar } \\
\text { Islands }\end{array}$ & Coastal (Island) & 6.1 .1989 & $\begin{array}{l}\text { Carnicobar } \\
\text { Islands }\end{array}$ & 885 & $\begin{array}{c}\text { Campbell Bay, Chingen } \\
\text { Kakana, Banaga, Indira } \\
\text { Pt. }\end{array}$ & Marine crocodiles \\
\hline 7 & Manas & $\begin{array}{c}\text { Eastern } \\
\text { Himalayas }\end{array}$ & 14.3.1989 & Assam & & $\begin{array}{c}\text { Kokrajhar, Kamrup, } \\
\text { Nalbari, Barpeta, } \\
\text { Darang }\end{array}$ & $\begin{array}{l}\text { Golden langur, red } \\
\text { panda }\end{array}$ \\
\hline 8 & Similpal & $\begin{array}{c}\text { Deccan } \\
\text { peninsula (MAB) }\end{array}$ & 21.6.1994 & Odisha & 4374 & Mayurbhanja & $\begin{array}{l}\text { Gaur, Royal Ben gal } \\
\text { Tiger, Wild elephant }\end{array}$ \\
\hline 9 & $\begin{array}{c}\text { Dibru } \\
\text { Saikhowa }\end{array}$ & $\begin{array}{c}\text { Eastern } \\
\text { Himalayas }\end{array}$ & 28.7.1997 & Assam & 765 & Debrugarh \& Tinsukia & Golden langur \\
\hline 10 & $\begin{array}{l}\text { Dihang- } \\
\text { Dibango }\end{array}$ & $\begin{array}{c}\text { Eastern } \\
\text { Himalayas }\end{array}$ & 02.9 .1998 & $\begin{array}{l}\text { Arunachal } \\
\text { Pradesh }\end{array}$ & 5112 & $\begin{array}{l}\text { Siang (upper/west), } \\
\text { Upper Dibang valleys }\end{array}$ & $\begin{array}{c}\text { various Leopards/ } \\
\text { red panda, Pine } \\
\text { Jungles } \\
\end{array}$ \\
\hline 11 & Panchmarhi & Semi-arid (MAB) & 3.03 .1999 & M.P. & 4981 & $\begin{array}{l}\text { Betul, Hosangabad, } \\
\text { Chhindwara,Shimoga }\end{array}$ & $\begin{array}{c}\text { Squirrels flying or } \\
\text { giant }\end{array}$ \\
\hline 12 & $\begin{array}{c}\text { Kanchenzong } \\
\mathrm{a} \\
\end{array}$ & $\begin{array}{c}\text { Eastern } \\
\text { Himalayas }\end{array}$ & 7.2 .2000 & Sikkim & 2931 & North \& west Sikkim & $\begin{array}{c}\text { Snow leopard /red } \\
\text { panda } \\
\end{array}$ \\
\hline 13 & $\begin{array}{l}\text { Agasthyamala } \\
\text { i Hills }\end{array}$ & Western Ghats & 12.11.2001 & T.N., Kerala & 3500 & $\begin{array}{c}\text { Thiruneveli, Kanya } \\
\text { kumari, Kollam, Patha } \\
\text { namthita, Thiruan }\end{array}$ & $\begin{array}{l}\text { Nilgiri Tahr, } \\
\text { Elephants }\end{array}$ \\
\hline 14 & $\begin{array}{l}\text { Achanakamar } \\
\text { to } \\
\text { Amarkantak } \\
\end{array}$ & $\begin{array}{c}\text { Semi-Arid } \\
\text { (Maikela Hills) }\end{array}$ & 30.5 .2005 & $\begin{array}{c}\text { M.P. \& } \\
\text { Chhattisgarh }\end{array}$ & 3835 & $\begin{array}{l}\text { Annupur, Dindori Chh- } \\
\text { garh \& Bilaspur in MP }\end{array}$ & Leopard, Chital, Gaur \\
\hline 15 & Rann of Kutch & $\begin{array}{c}\text { Western } \\
\text { Himalayas, }\end{array}$ & 29.1.2008 & $\begin{array}{l}\text { Gujarat, } \\
\text { GRK/LR }\end{array}$ & 12454 & $\begin{array}{l}\text { Kachchh, Rajkot, } \\
\text { Surendranagar }\end{array}$ & $\begin{array}{l}\text { Wild, asses, nilgai, } \\
\text { desert fox }\end{array}$ \\
\hline 16 & $\begin{array}{l}\text { Cold desert } \\
\text { Trans-Him } \\
\text { alayan) } \\
\end{array}$ & $\begin{array}{c}\text { Western } \\
\text { Himalayas }\end{array}$ & 28.8 .2009 & $\begin{array}{l}\text { J\&K, } \\
\text { H. P. }\end{array}$ & 7770 & $\begin{array}{l}\text { Kargil in J\&K and Sipti } \\
\text { in H.P. Kinnaur } \\
\text { (Chandratal, Sarchu) }\end{array}$ & Snow leopards \\
\hline 17 & $\begin{array}{c}\text { Sheshachalam } \\
\text { Hills }\end{array}$ & Eastern Ghats & 20.9 .2010 & $\begin{array}{l}\text { Andhra } \\
\text { Pradesh, } \\
\text { Odisha }\end{array}$ & 4756 & $\begin{array}{l}\text { Chittoor, Cudappa, } \\
\text { Nallamalai, Tirupati, } \\
\text { Sunki, Deomalli hills. } \\
\text { Jeypore hill, Odisha, }\end{array}$ & $\begin{array}{c}\text { Mouse Deer, 4- } \\
\text { Horned antelope, } \\
\text { giant Squirrel, Indian } \\
\text { Civet }\end{array}$ \\
\hline 18 & Panna & River Valley & 25.8 .2011 & M.P. & 2998 & $\begin{array}{l}\text { Panna, Raigarh \& } \\
\text { Chhattarpur }\end{array}$ & $\begin{array}{l}\text { Tiger, Chital, Sloth } \\
\text { bear, Sambhar }\end{array}$ \\
\hline
\end{tabular}

\subsection{Marine protected area (MPA's)}

The water cover of earth can be divided into $31 \%$ national water and 61\% high seas. At present MPA's of national waters cover $23684818 \mathrm{Km}^{2}(16.77 \%)$ of the oceans but only $2618153 \mathrm{Km}^{2}(1.18 \%)$ of high seas are protected. In 2000, MPAs covered was about $2 \mathrm{Mkm}^{2}$ $(0.7 \%$ of the Ocean) which has been increased to about $23 \mathrm{MKm}^{2} \quad(7.26 \%)$ of the ocean at present. Development in MPA area in high seas is negligible https://www.protected planet.net/marine. Only one percent of India's vast coastline is well protected.

India has $7516.6 \mathrm{~km}$ of coastline $(5422.6 \mathrm{~km}$ along the coast, $2094 \mathrm{~km}$ along island periphery). The coastal stretch has $372.42 \mathrm{Km}^{2}$ economic zone, continental shelf $2.02 \times 10^{6} \mathrm{Km}^{2}$ and a territorial water area of $193834 \mathrm{Km}^{2}$ spread over nine (9) coastal states and two (2) Union Territories (UTs). The coastal stretch consists of $43 \%$ sand, $36 \%$ muddy, $11 \%$ rocky, and $10 \%$ marshy lands https:/ / www. geographyandyou.com/ climate-change/environment/ coastal - marine -ecosystems. India.

\subsubsection{Coral reefs India}

A ridge of rock in the sea formed by the growth and deposit of coral susceptible to coastal development, agriculture, pollution, and other human activities resulting in sedimentation are the coral reefs. There is $600000 \mathrm{Km}^{2}$ area in the globe (Smith 1978) including $60 \%$ of the Indian Ocean region in SE Asia. The coral reef areas in India waters territory are estimated as 2375 Km Wafar 1990[18], DOD and SAC, 1997[19],. The coral reef zones of India has species biotic algae 
(180types), seaweeds (20 types), seagrasses (20 types), Poriferans (115species), Crustaceans (5 varieties), Echinoderms (110types), and bony fishes varieties of 600 species Jyoti S. et al., 2016. The Coral reef Ecosystem of Andaman and Nicobar has the most biodiverse reefs comprising 235 Species of corals, 111 Species of soft corals, 112 Species of sponges, 411 Species of crustaceans, 1422 Species of molluscs, 430 Species of echinoderms, 750 Species of fishes, 4 Species of mammals, 14 Species of reptiles, 50 species of Marine birds, and 64 species of Algae including rare varieties of Coconut crabs Rajan et al., 2011 and Jay Prakash et al 2014. Coral reefs prevent sediments from washing up the shoreline and protect coastline habitats, sequester for $\mathrm{CO}_{2}$, augments tourism and used for medicine. The threats to reef kingdom are sediment dredging and logging, san mining, trans-boundary poaching, careless tourism, and bleaching. Details of coral reefs in India is given in Table 4.

For protection of reef kingdom the federal initiatives are establishment of Indian Coral Reef Monitoring Network (ICRMN), Database Network and Website on Coral Reefs, Establishment of National Coral Reef Research Centre at Port Blair, Inclusion of Corals in Schedule I of the Wild Life Protection Act, 1972,National Focal Points of Global Coral Reef Monitoring Network (GCRMN), International Coral Reef Initiative (ICRI) and Coral Reef Degradation in Indian Ocean (CORDIO), Implementation of UNDP-PDFB Project on Management of Coral Reefs in A\&N islands and Implementation of India-Australia Training and Capacity Building (IATCB) Proj. on Coral Reefs Table 6.

Table 6: The status of coral reefs and their location in Oceans and Bays around India till 2016

\begin{tabular}{|c|c|c|c|c|c|c|c|}
\hline \# & Coral reefs(Ind) & Islands & Area & species & Reef forms & Location/Protection & References \\
\hline & Name of coast & No & $\mathrm{Km}^{2}$ & No & Forms & & \\
\hline 1 & $\begin{array}{l}\text { Goa coast (Arabian } \\
\text { Sea) }\end{array}$ & 3 & $\approx 30$ & 29 & Patchy & $\begin{array}{l}\text { Ratnagiri Redi,, Malvan \& } \\
\text { Bombay (S) Grande, Bat } \\
\text { Islands, St. George Island }\end{array}$ & \multirow{7}{*}{$\begin{array}{c}\text { Pillai,1996 Dey et } \\
\text { al., 2015 } \\
\text { http://eprints.cmf } \\
\text { ri.org.in/9874/1/P } \\
\text { hilipose_11.pdf } \\
\text { Pillai1996, } \\
\text { http://www.fao.or } \\
\text { g/docrep/X5627E } \\
\text { /x5627e06.htm, } \\
\text { Jyoti S. et al., 2016 } \\
\text { Krishnamurthy, } \\
\text { 1987[25], DOD \& } \\
\text { SAC, 1997 } \\
\text { Pillai \& } \\
\text { Jasmine1989.'SAC, } \\
\text { 2010, } \\
\text { http://niobioinfor } \\
\text { matics.in/corals/c } \\
\text { orals, Pillai,G.,1996 }\end{array}$} \\
\hline 2 & Kerala coast & 6 & $\approx 05$ & 29 & Fringing reef & Artificial & \\
\hline 3 & $\begin{array}{l}\text { Palk Bay }\left(9^{\circ} 17^{\prime} \mathrm{N} \text { and }\right. \\
\left.79^{\circ} 15^{\prime}\right)(\mathrm{BOB}, \text { Indian } \\
\text { Ocean) TN }\end{array}$ & 2 & $\approx .600$ & $>60$ & $\begin{array}{l}\text { flat reef and } \\
\text { sandy beaches, } \\
\text { fringing reef }\end{array}$ & $\begin{array}{l}\text { Rameswaram, soft corals, } \\
\text { octocorals and other sessile } \\
\text { benthos }\end{array}$ & \\
\hline 4 & $\begin{array}{l}\text { Gulf of Kutch } 22 \cong 15^{\prime} \\
-23^{\circ} 40^{\prime} \mathrm{N} 68^{\circ} 20^{\prime}- \\
70 \cong 40^{\prime} \text { E, Gujarat, } \\
\text { Arabian Sea }\end{array}$ & 40 & 352.5 & 37 & $\begin{array}{l}\text { Platform reefs } \\
\text { and fringing } \\
\text { reefs (patchy) }\end{array}$ & $\begin{array}{l}\text { All corals, Acro- pora, } \\
\text { Pocillopora, Stylophor }\end{array}$ & \\
\hline 5 & $\begin{array}{l}\text { Gulf of Manner }\left(78^{\circ}\right. \\
\left.12^{\prime} \mathrm{E} \text { and } 79^{\circ} 14^{\prime} \mathrm{E}\right) \\
\text { the Indian Ocean }\end{array}$ & 21 & 94.3 & 96 & $\begin{array}{l}\text { Fringing reef, } \\
\text { Shore platform, } \\
\text { patch, }\end{array}$ & $\begin{array}{c}\text { coral pinnacles \& atolls } \\
\text { Tuticorin- Rameswaram } \\
\text { Biosphere reserve). }\end{array}$ & \\
\hline 6 & $\begin{array}{l}\text { Lakshadweep islands } \\
19-12^{\circ} \mathrm{N} 72-74 \stackrel{\circ}{ } \mathrm{E} \\
\text { Arabian Sea }\end{array}$ & 36 & 933.7 & 105 & $\begin{array}{l}\text { Atolls (12) } 3 \\
\text { reefs, } 5 \\
\text { submerged } \\
\text { banks ) }\end{array}$ & $\begin{array}{l}\text { Acropora, Porites, Diploastrea, } \\
\text { Helio pora, Goniastreareti } \\
\text { formis \& Lobo phyllia. } \\
\text { Restricted area }\end{array}$ & \\
\hline 7 & 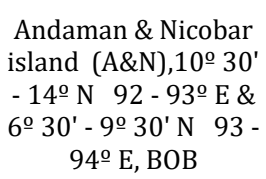 & 572 & 1021 & $\begin{array}{l}82(\mathrm{An}) \\
103 \\
(\mathrm{Ni})\end{array}$ & $\begin{array}{l}\text { Barrier reefs \& } \\
\text { Fringing reefs }\end{array}$ & $\begin{array}{l}\text { M. G. MNP Park at Wan door, } \\
\text { fringing reefs }\end{array}$ & \\
\hline
\end{tabular}

\subsubsection{Marine Species coverage India}

ISFR 2017 reported that the total mangrove cover in India is $4921 \mathrm{~km} 2$ (has enlarged by $181 \mathrm{Km} 2$ in 7 out of 12 mangrove states). Mangroves have a unique biome instituted in the estuaries, creeks, lagoons, marshlands and mudflats. These mangroves have enriched flora and fauna that provides numerous ecoutilities. Table 9: The marine biodiversity of and species in India http:// iced.cag.gov.in/wpcontent/uploads/2016-17/) \& Wafar et. al. (2011) Venkstratnm K., 2005 had reported that the coastal marine system of India had 844 species of seaweeds (highest Palk bay: 302species), Sponges of 65 families 169 genera, and 451 species (highest 275 in Palk bay), hard Corals of 15 families 60 genera, and 218 species (highest in 180 species in Nicobar islands) UNEPWCMC and IUCN (2018). Status of marine species in and around Indian territory is given in Table 7.

\subsubsection{Marine Ecosystem services}

The utilities provided by the mangroves are fisheries, recreation, coast stabilization, storm protection, and carbon sequestration. The other contributions are water and air purification, waste assimilation, nutrient retention, and bio-diversity reservation. The widespread mangroves along the east coast are Godavari - Krishna (A.P.), Sundarbans (WB), Bhitarkanika, Chilika (Odisha), A\&N islands and Pichavaram mangroves along the east coast of India. In west coast of India, the mangroves are found from Bombay to Panaji and in the Lakshadweep islands of India. Indian coastline is home to 25 families, 63 genera and 69 species. The Floral and faunal species were 420 and 1862 , 
Table 7: Marine species population coverage in marine areas India

\begin{tabular}{|c|c|c|c|c|c|c|c|}
\hline Marine Species & Population & Species & Populn & Species & Populn. & Species & Populn \\
\hline Protista & $1064+$ & Brachiopoda & 3 & Echinodermata & 765 & Marine Plants & \\
\hline Animalia & & Arthropoda & & Hemichordata & 12 & Diatoms & $200+$ \\
\hline Porifera & $486+$ & Crustacea & 3498 & Chordata & & Dinoflagelates & $90+$ \\
\hline Cnidaria & $842+$ & Pycnogonida & 16 & Protochordata & $119+$ & Macro algae & 844 \\
\hline Ctenophora & 12 & Merostomata & 2 & Pisces & 2546 & Sea grasses & 14 \\
\hline Platyhelminthes & 350 & Sipunculida & 35 & Amphibia & 3 & Mangroves & 39 \\
\hline Gastrotricha & 75 & Echiura & 33 & Aves & 145 & & \\
\hline Kinorhyncha & 99 & Tardigrada & $3310+$ & Mammals & 29 & & \\
\hline Annelida & 338 & Chaetognatha & $30+$ & Reptiles & 35 & & \\
\hline Mollusca & 3370 & Entoprocta & 8 & Aves & $145+$ & & \\
\hline Bryozoa & $200+$ & Phoronida & 3 & Mammalia & 25 & & \\
\hline
\end{tabular}

\subsubsection{Key issues with Marine ecosystem}

It is forecasted that Global marine ecosystem shall be unsustainable and degraded by $60 \%$ by the year 2100 . About $35000 \mathrm{Km}^{2}$ of mangroves has been removed globally from great acceleration period of the Anthropocene epoch (1980 to 2010). World's Ocean area $(1 \%)$ and land mass (12\%) only have been protected from biodiversity losses and rest are left for human exploitation. The phytoplankton in marine climate provides about half the oxygen of the globe. The Sea shall be an inhospitable area for marine flora and fauna in future. It is estimated that mangroves, salt marshes and meadows of seagrass can absorb, or retrieve carbon from $\mathrm{CO}_{2} @ 50$ times in comparison to the identical area of tropical forests Mishra S. P. $2017^{[51]}$. Ocean acidification has invited catastrophe for the vast aqua fauna ecosystem, which derives $\approx 15 \%$ of present food from the sea. The concentration of $\mathrm{CO}_{2}$ which was almost constant $(\approx 250 \mathrm{PPT})$ during preAnthropocene epoch has crossed $400 \mathrm{ppm}$ at present. Hence the biodiversity of the marine ecosystem is under apocalyptic jeopardy which needs immediate attention. Direct and indirect disposal of all liquid wastes, excess use of pesticides and nitrogen-rich fertilizers are the main drivers of the threat. When the rivers discharge to sea, pollute the marine water hypoxic and form dead zones in the offshore region http://www.unesco.org/ new/en/natural-sciences/ ioc-oceans/ focus-areas/rio-20-ocean.

\section{Endemic species in India}

Endemic species grows naturally in an isolated/single geographic area of small or large size depending upon their geographic range, population size, and habitat demands. About 6850 species of Indian flora were estimated endemic (60\% of flowering plants). The endemic species in major biogeographic areas are Eastern Himalaya and North-eastern region (2500), Western Ghats and Peninsular India (2600), NorthWestern Himalaya (800) and Andaman \& Nicobar Islands (200) https://www.ukessays.com/ dissertation/examples/biology. The endemic species are concentrated in Himalayas, $A \& N$ Islands and WG
Hills. About 3169 species grow in the Himalayas and 2045 species in Peninsular India including Nepal and Bhutan Chatterjee ( 1962) ${ }^{[52]}$. Balakrishnan (1996) ${ }^{[53]}$ estimated > 6100 endemic species out of total 17500 species of flowering plants (more than 36\%) in India.

Nayar (1996) mentioned 147 genera and 5725 species of flowering plants as endemic to the Indian region. The threat to endemism occurs due to habitat loss, overhunting, invasive species, non-active predators, disease-causing species, competitors, fragmentation and above all anthropogenic interventions due to draining and filling of freshwater wetlands. http://mjcet envsci.blogspot .com/2013/11. About 55 species of birds are endemic to India found mostly in the Western Ghats, eastern India along the mountain chains and the Andaman and Nicobar Islands

\subsubsection{Species/taxa listing}

The (IUCN), reported 1,737,248 numbers species out of which 26197 numbers of species are threatened (2018) (Fig 4). IUCN has identified 973, 988 and 1067 threatened species in the years 2014, 2015 and 2018 respectively with an increased trend in India. It is found that the highest numbers of taxa are Arthropods (43\%), followed by Insects (38\%) of the total taxonomy and mammals are 4629 in numbers.

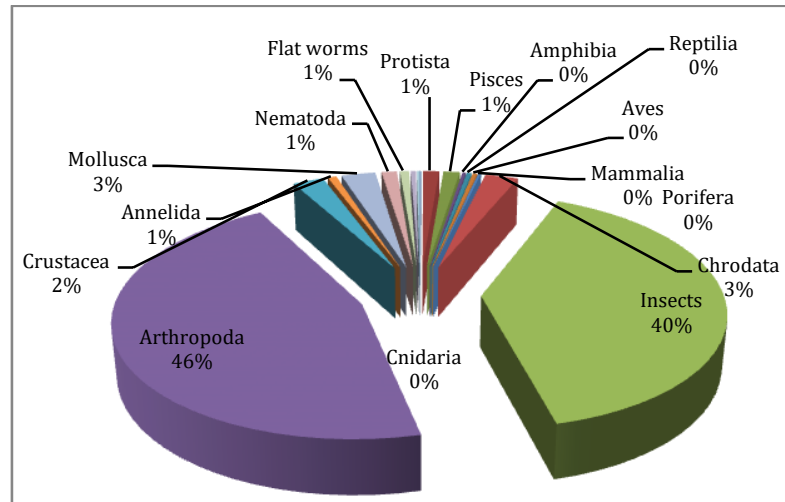

The estimated species (\%) in taxonomic groups in the World, year 2014, Source : ZSI India 2015

Fig 5: Different major species exists throughout the world (Source: Zoological Survey of India) 


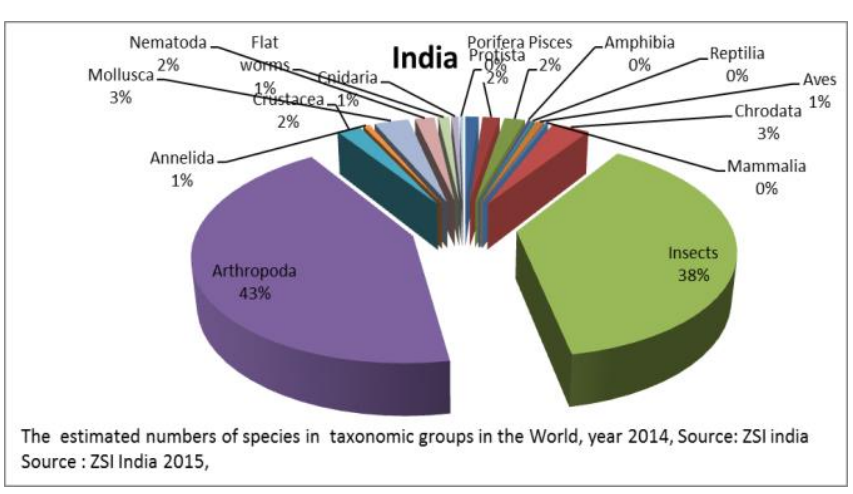

Fig 6: Status of flora and faunal species changes in of India (Source: ZSI - 2015)

Table 8: Biodiversity changes of India and the globe inclusive Indian marine Biodiversity, IUCN 2018, Arisdason et. al.,2017, .http://www.bsienvis.nic.in/Database/Floral_Statistics_of_India_2017,http://www.envfor. nic.in /soer /2001 /ind_bio.pdf \& http:/ /cdn. Intech open. com/pdfs/46541

\begin{tabular}{|c|c|c|c|c|c|c|c|c|}
\hline VERTEBRATES & $\begin{array}{c}\text { Species } \\
\text { MOEF } \\
1999\end{array}$ & $\begin{array}{c}\text { Species } \\
\text { Population } \\
2018 \\
\end{array}$ & $\begin{array}{c}\text { Threatened } \\
\text { species } \\
(2007) \\
\end{array}$ & $\begin{array}{c}\text { Threatened } \\
\text { (2018) }\end{array}$ & $\begin{array}{c}\text { Species } \\
\text { Population } \\
\text { (1998) }\end{array}$ & $\begin{array}{c}\text { ZSI } \\
\text { species } \\
2017 \\
\end{array}$ & $\begin{array}{l}\text { Endemic } \\
\text { Species } \\
2018\end{array}$ & $\begin{array}{c}\text { Endemic } \\
\text { Threatened } \\
\text { IUCN (2018) }\end{array}$ \\
\hline & \multicolumn{4}{|c|}{ THE GLOBE } & \multicolumn{4}{|c|}{ INDIA } \\
\hline & No & No & No & No & No & No & No & No \\
\hline Mammals & 4629 & 5677 & 1094 & 1210 & 390 & 427 & 46 & 28 \\
\hline Birds & 9026 & 11122 & 1217 & 1469 & 1232 & 1340 & 74 & 23 \\
\hline Reptiles & 5817 & 10711 & 422 & 1236 & 456 & 572 & 0 & 0 \\
\hline Amphibians & 5150 & 7866 & 1808 & 2100 & 350 & 388 & 167 & 70 \\
\hline Fishes & 21723 & 33900 & 1201 & 2385 & 2546 & 3324 & 7 & 1 \\
\hline \multicolumn{9}{|l|}{ INVERTEBRATES } \\
\hline Insects & 987989 & 1000000 & 623 & 1478 & 53400 & 65047 & NA & NA \\
\hline Molluscs & 66535 & 85000 & 978 & 2195 & 5070 & 5189 & 5 & 0 \\
\hline Crustaceans & 31259 & 47000 & 460 & 730 & 2934 & 3796 & 60 & 3 \\
\hline Velvet Worms & 119 & 165 & 9 & 9 & 1 & 1 & 0 & 0 \\
\hline Others & 87121 & 68658 & 24 & 146 & 20752 & 20609 & 0 & 0 \\
\hline PLANTS & BSI 2009 & & & & BSI 2009 & & & \\
\hline Mosses & 14500 & 16236 & 80 & 76 & 2500 & 2478 & NA & NA \\
\hline Ferns and Allies & 10000 & 12000 & 139 & 246 & 1200 & 1289 & 0 & 0 \\
\hline Gymnosperms & 650 & 1052 & 321 & 401 & 67 & 79 & 4 & 3 \\
\hline Flowering Plants & 250000 & 268000 & 7899 & 12049 & 17527 & 18386 & 4 & 3 \\
\hline Algae & 40000 & 13154 & 9 & 9 & 7175 & 7357 & NA & NA \\
\hline Lichens & 13500 & 17000 & 2 & 10 & 2223 & 2511 & NA & NA \\
\hline Virus/Bacterias & 8050 & 11813 & & & 850 & 986 & & \\
\hline Mushrooms & 1200 & 31496 & 1 & 33 & 10000 & 15115 & NA & NA \\
\hline Brown Algae & NA & 3784 & 6 & 6 & 0 & 0 & $\mathrm{NA}$ & NA \\
\hline TOTAL & NA & 1737248 & 16308 & 26197 & NA & & NA-N & available \\
\hline
\end{tabular}

But in the case of arthropods the numbers of species were $46 \%$, the insects are $40 \%$ and corresponding Mammalia in India were 423 in the year 2014. From the distribution of species it is inferred that the arthropods and insects are large in number whereas the amphibians, reptiles and mammals are the least in number in the globe and so also in India Table 8.

\subsubsection{Statistics of Domesticated Farm animals}

There are evolutionary interactions of mammalian (family Bovines) species used for agricultural activities and food production by domesticating wild animals since the Holocene epoch. India has 12 primary aboriginal cultivated plants centers and domesticated animals https:// www.omicsonline.org/blog/ 2015/
$08 / 27 / 19447$. It has the homeland of 167 endemic plant species of cereals, fiber crops millets, fruits, condiments, vegetables, pulses, and oilseeds, and 169 breeds of domesticated animals. Global enumeration of the livestock's was done during the current Anthropocene epoch from mid-20 th century only. ICARNational Bureau of Animal Genetic Resources, Karnal (NBAGR) have recorded in 2017 that nine new classes of livestock and poultry i.e goat ( 2 breeds), and cattle, pig, horse, chicken, and indigenous geese, yak, duck one breed each. Present enumeration of indigenous breeds of India is 169, including cattle (41nos), Buffalo (13 nos), goat (28 nos), sheep (42 nos), horses \& ponies (7 nos), came (19 nos), pig (7 nos) , one (1no) each for $r$ donkey, yak, duck and geese and for chicken (18 nos). So also there are evolutionary relationships 
between aqua fauna and avifauna used for nutrition and agriculture production. Such birds are an emu, nandu, ostrich, turkey, ducks, goose, chicken and many more Table 9. Studies reveals that the growth rate of the chicken has the highest increase in comparison to any other birds and animals Mishra et al, 2018.

Table 9: Status of Domesticated Bovines species of the world, Asia, India and Odisha during 2017

\begin{tabular}{|c|c|c|c|c|c|c|c|}
\hline Bovine & World & Asia & India & India & Odisha & New reports & Species (Odisha) \\
\hline Species & $\begin{array}{l}\text { FAO- } \\
2000\end{array}$ & $\begin{array}{c}\text { FAO0 } \\
0\end{array}$ & $\begin{array}{c}\text { ICAR20 } \\
16\end{array}$ & $\begin{array}{l}\text { NBAGR } \\
2017\end{array}$ & Das -16 & NBAGR & Das et al., 16 \\
\hline Cattle & 787 & 190 & 30 & 41 & 5 & 1, Laxmi, Assam & $\begin{array}{c}\text { Chilika, Birnjharpuri, Motu, Ghoomsoori \& } \\
\text { Kharial }\end{array}$ \\
\hline Buffalo & 72 & 57 & 10 & 13 & 7 & No addition & $\begin{array}{l}\text { Chilika, Manda, Arani, Kujanga, Jirangi, } \\
\text { Kalahandi, parala khe mundi }\end{array}$ \\
\hline Sheep & 910 & 226 & 42 & 28 & 9 & Nil & $\begin{array}{l}\text { Kendrapada, Ganjam, Kuzi, Bolan gir, } \\
\text { Machhakund, Erka, Kathargada, } \\
\text { Dharmgada, Chhotanagpuri }\end{array}$ \\
\hline Goat & 351 & 126 & 22 & 42 & 7 & $\begin{array}{l}\text { 2, Salem black TN \& } \\
\text { Sumine Nagaland }\end{array}$ & $\begin{array}{c}\text { Malkanagiri, Black Bengal, Gan jam (plains, } \\
\text { \& Hills), Raighar, Koraput and } \\
\text { Narayanpatna }\end{array}$ \\
\hline Pig & 353 & 157 & 3 & 7 & 4 & Zovawak, Mizoram & $\begin{array}{l}\text { Burudi (KPT), Golla (Ganjam),Jhinga, and } \\
\text { Wild }\end{array}$ \\
\hline Ass/Yak & 77 & 17 & 3 & 2 & 1 & 1, Yak,Arunachali & Nil \\
\hline $\begin{array}{l}\text { horse/pon } \\
\text { ies }\end{array}$ & 384 & 72 & 6 & 7 & Nil & $\begin{array}{l}\text { Kachchhi- } \\
\text { Sindhi West India }\end{array}$ & Nil \\
\hline Camel & 56 & 14 & 8 & 9 & 0 & nil & Nil \\
\hline Poultry & 606 & 72 & 18 & 18 & 6 & 1, Hansli, Odisha & $\begin{array}{c}\text { Phulbani, Dhinki, Aseel, Vezaguda, Hansli, } \\
\text { Hazara, Kalahandi }\end{array}$ \\
\hline $\begin{array}{l}\text { Ghoose/D } \\
\text { uck }\end{array}$ & & & & & 3 & $\begin{array}{l}\text { 2, Kashmir Anz } \\
\text { (J\&K), Pati (Assam) }\end{array}$ & Rajhansa, Muskovy, Koraput, \\
\hline
\end{tabular}

(Source: http://www. nbagr.res.in/registeredbreed.html and finding

\subsection{Red Listed Biodiversity}

Polynomial model indicating the number of threatened species is increasing gradually and the globe may be heading towards mass extinction. The IUCN Red-listed data $2018^{[43]}$ of the total numbers of threatened species of the globe and their trend is exhibited in Fig 10 (A) for vertebrates and the data indicate that the plant Taxas are becoming more endangered in India followed by fishes Fig (10B) for invertebrates.

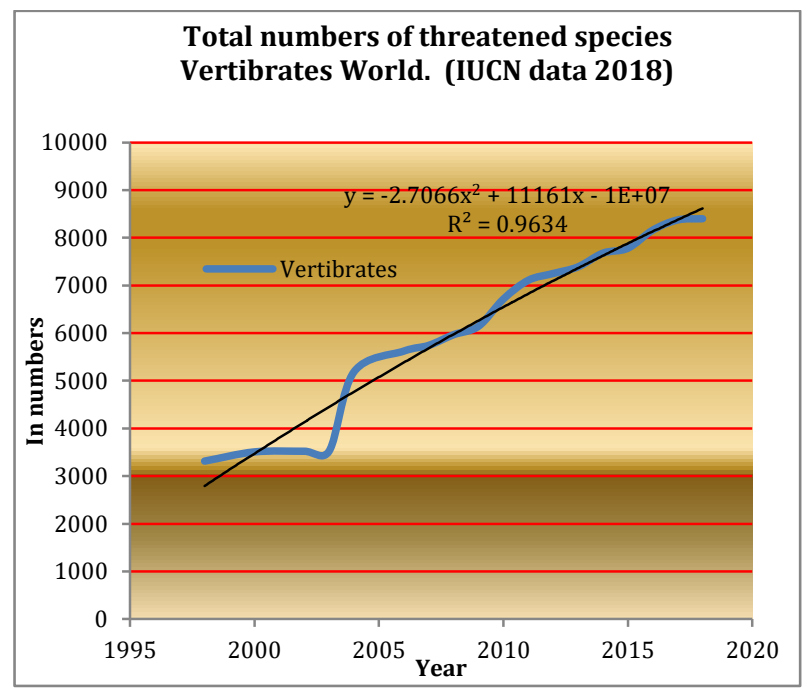

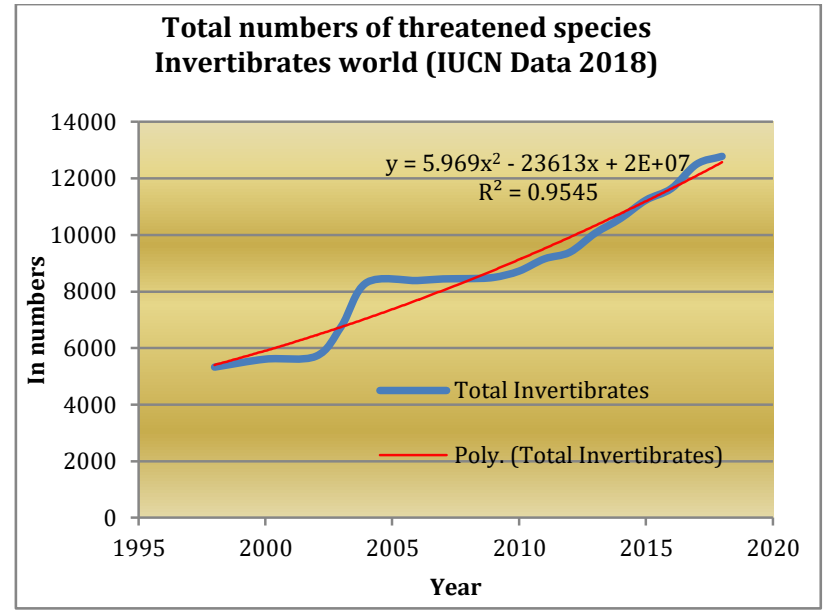

Fig 10: The Global trend of threatened species Vertebrates (A) \& Invertebrates (B) (source: IUCN 2018)

The present time series data can be statistically analyzed as the coefficient of regression is 0.9634 (Fig 6A) for vertebrates and 0.9534 (Fig 6B) for invertebrates. The regression model of the series of data follows an increasing Enumeration of the major threatened species in the global scenario enlisted by IUCN in its major category has been published in the current year 2018. The annual changes in the numbers of species though could not picture the trend profile as 
new threats impinge but the main threats for the change remain persistent. However knowing the time series of the number of threatened species, some concept of the trend could be derived in the status of biodiversity. The interrupted time series from 1996 to 2006 and continuous time series onwards till 2018 have been considered. $\mathrm{R}^{2}$ is considered as a statistical measure of how close the data are to the fitted regression line.
The IUCN has listed classification of existing, extant and extinct species for future biodiversity enumeration, conservation and management used by the environmentalists. The existing extant species assessed by IUCN and reported as EW - Extinct in the Wild, CR - Critically Endangered, EN - Endangered, VU Vulnerable, NT - Near, Threatened, DD - Data Deficient, LC - Least Concern.

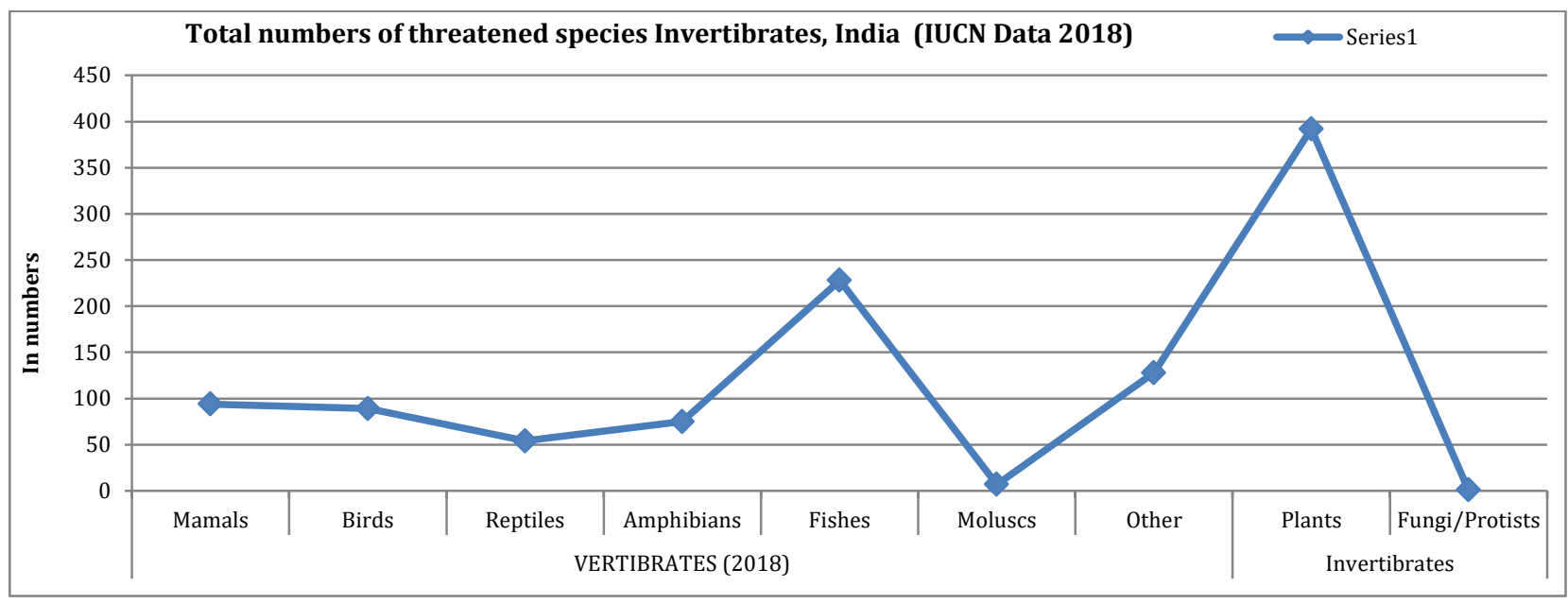

Fig 11: Total numbers of threatened species (animals \& plants) India, (Source IUCN 2018)

As per IUCN report 2018[43], the accepted percentage of threatened species cycads plants (63\%), amphibians (41\%), reptiles $(35 \%)$, dicots $(35 \%)$, conifers $34 \%$, corals $33 \%$; sharks \& rays $31 \%$, crustaceans $27 \%$, mammals $25 \%$, birds $13 \%$, fishes $7.5 \%$, gastropods (snails) 7.5\%. The discontinuous time series data for the period 1996 to 2018 of the critically endangered faunal species of the vertebrates and invertebrates were studied and are in Fig 11

\subsubsection{IUCN Statistics and Classifications}

The features that contribute to the variant biodiversity of the globe are topography, elevation, wetlands, forests, ocean, grassland, deserts, position on the earth, coastal, marine biome and the anthropogenic pressure. Different species harboring earth surface and their changes in $21^{\text {st }}$ century indicate that species like amphibians have suffered more than other species from 2003 onwards. Reptiles and the fishes are also becoming critically endangered (CR) from 2012 onwards in the world Fig 12 and Fig 13

The data series of IUCN 2018 depicts the mammalian population inclusive the Homosapiens are changing erratically. The coefficient of regression values ( $\mathrm{R}^{2}$ values) obtained as 0.797 and the best fit statistical model is a polynomial function. There is a rise in the trend line of threatening of mammalian species in the $21^{\text {st }}$ century. In overall there is an increase in the number of endangered species and the sixth extinction is inching forward in the $21^{\text {st }}$ century of the Anthropocene epoch Fig -10.
The barriers and the limiting factors that change in the population of any species that makes difficult for its growth, survival, or reproduction are climates, temperature, altitude, invasive alien species, topography, moisture, $\mathrm{CO}_{2}$, light, nutrients, water quality, ambient air, habitation, and above all the anthropogenic activities. The invasive alien species (IAS) is the species that has anthropogenic intrusion to a native bio-system from outside of its usual past or present dispersal and whose invasion (become 5-20\%) threaten or have a negative impact and problematic to the existing biological diversity. All IAS are not problematic in nature. The time series status of mammals is in Fig 14 (a) \& 14 (b).

Species invasion is geospatial and dynamic but generally slow and complicated. It is influenced by the geologic, geomorphic and meteorology of the area. Invasion and extinction may disrupt or change the ecosystem partly or completely. Presence of IAS may split and gradually vanish. India has 1,599 species of alien plants of 841 genera and 161 families. The invasive and alien species shall tend to reduce the population size of other species by reducing their birth rate and immigration of other species. The causes of invasion of species occur due to the land breeze, by climatically and ecological paths or by sweepstake paths such as crossing mountain ranges or large water bodies. Generally the species have complex dynamic distribution with geospatial dawdling changes which may be permanent or temporal. IAS can alter the structure and composition of an ecosystem or even detrimental to the Eco services. For example the ipomeas and hyacinth (the aquatic plants) which is aboriginal species growing in water surface of South 
America has become IAS to continents of Africa, Asia and North America. The profuse invasion of species has badly affected the eco-health of water bodies by blocking and choking drainage system, navigation channels and canals so that the hydropower capacity, yield of crops, aqua catches, faunal diversity and accelerating the vector-borne diseases.

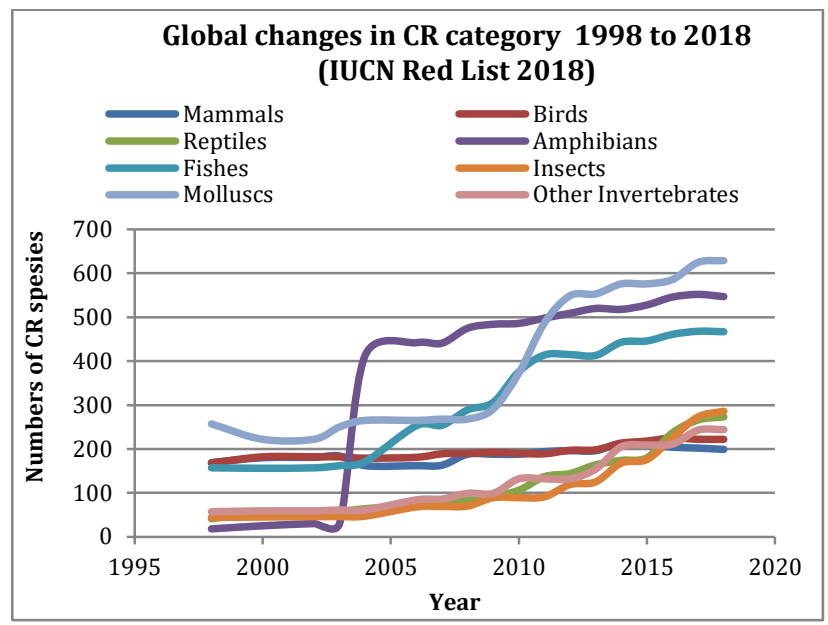

Fig 12: Global changes in the number of CR species 1996-2018; IUCN Red List 2018

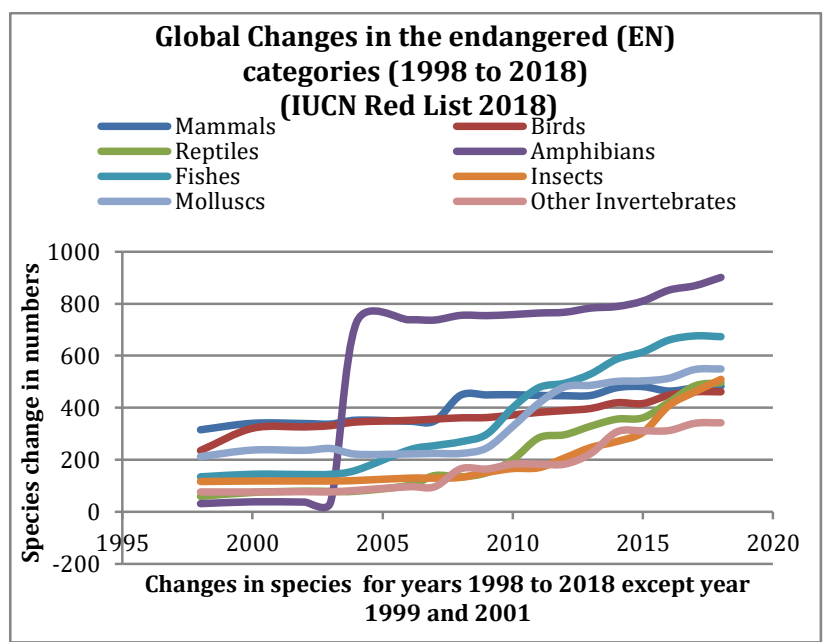

Fig 13: Global changes in the number of endangered species 1996-2018; IUCN Red List 2018

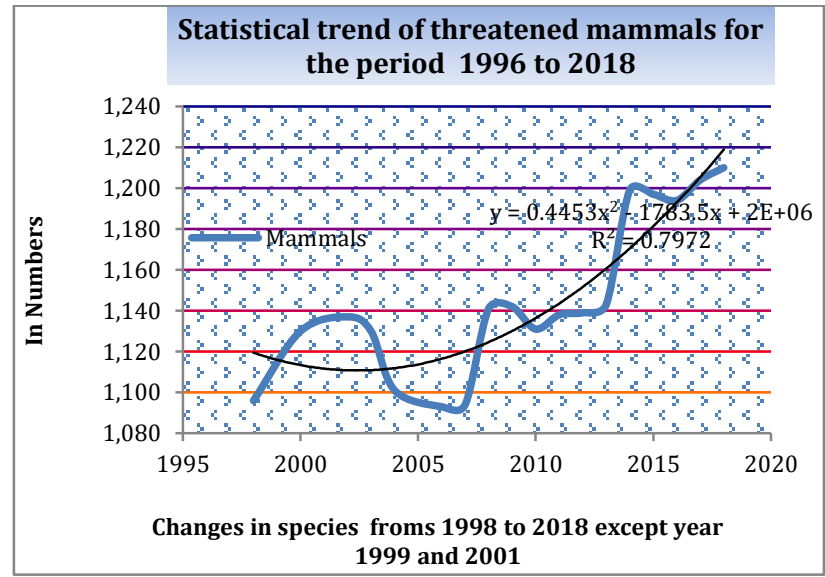

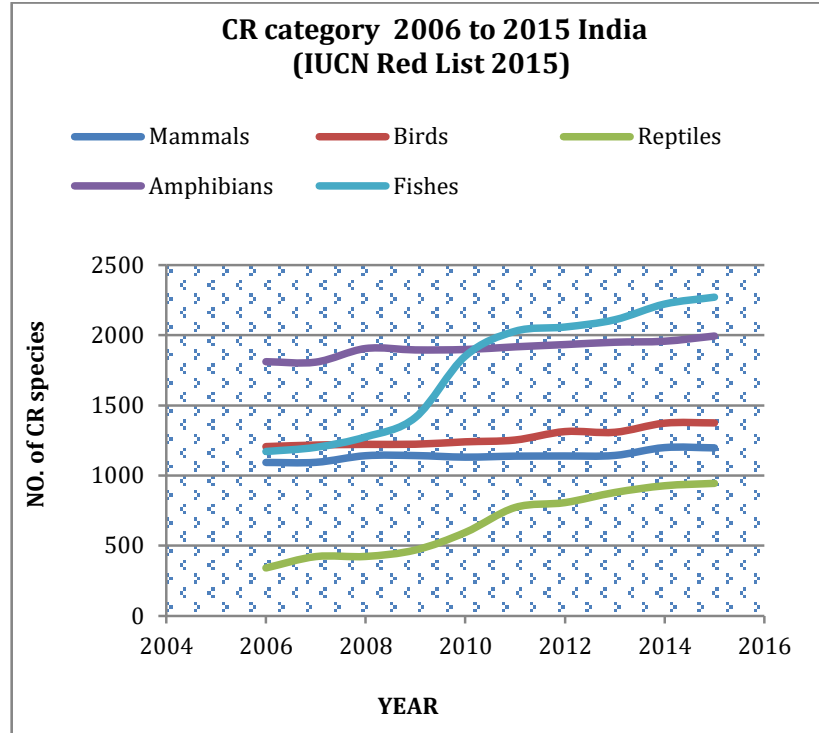

Fig 14 (a) \& 14 (b): The changes in the population of mammals for period, India, 1996 to 2018 (IUCN 2018)

\subsubsection{The invasive alien species}

Species invasion is geospatial and dynamic but generally slow and complicated. It is influenced by the geologic, geomorphic and meteorology of the area. Invasion and extinction may disrupt or change the ecosystem partly or completely. Presence of IAS may split and gradually vanish. India has 1,599 species of alien plants of 841 genera and 161 families. The invasive and alien species shall tend to reduce the population size of other species by reducing their birth rate and immigration of other species. The causes of invasion of species occur due to the land breeze, by climatically and ecological paths or by sweepstake paths such as crossing mountain ranges or large water bodies. Generally the species have complex dynamic distribution with geospatial dawdling changes which may be permanent or temporal. IAS can alter the structure and composition of an ecosystem or even detrimental to the Eco services. For example the ipomeas and hyacinth (the aquatic plants) which is aboriginal species growing in water surface of South America has become IAS to continents of Africa, Asia and North America. The profuse invasion of species has badly affected the eco-health of water bodies by blocking and choking drainage system, navigation channels and canals so that the hydropower capacity, yield of crops, aqua catches, faunal diversity and accelerating the vector-borne diseases. 


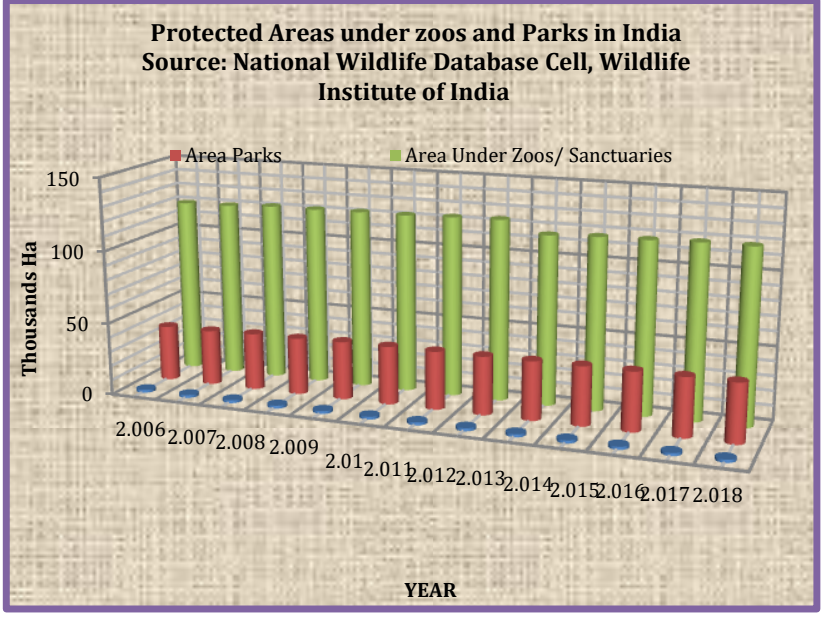

Fig 15: The protected areas under zoos and Parks in India (source: Wild Life Inst. Of India)
The biodiversity of India is under threat due to combined effects of natural and anthropogenic. Natural causes can be calamity and competition between species and IAS to create biological imparity while the anthropogenic pressures are deforestation, population growth, food production, agriculture, mining, urbanization, industrialization, grazing, overexploitation flora and fauna, enhanced mobilization, tourism. The utmost need of the great acceleration period of the present Anthropocene epoch we must have widespread and well demarcated protected areas for the uninterrupted habitation of the species. A large Network has been initiated by the federal government to protect the flora and fauna of India by the state forest departments. The protected areas cover $4.8 \%$ of the total geographical area of the country. The protected areas under zoo and botanical parks in India are in Fig 15.

Table 10: Status of the prominent national parks, Area, IUCN types and the year of establishment in India

\begin{tabular}{|c|c|c|c|c|c|c|c|c|}
\hline \# & Category & $\begin{array}{c}\text { Total } \\
\text { No. }\end{array}$ & $\begin{array}{l}\text { Biodiversity zone } \\
\text { (Name) }\end{array}$ & State & Famous Fauna & $\begin{array}{l}\text { IUCN } \\
\text { Type }\end{array}$ & $\begin{array}{l}\text { Area } \\
\mathrm{Km}^{2}\end{array}$ & Year \\
\hline 1 & \multirow{10}{*}{$\begin{array}{c}\text { National Parks } \\
\text { (NP) } \\
\text { Prominent }\end{array}$} & 116 & Jim Corbett & Uttarakhand & Tiger & IV & 1319 & 1936 \\
\hline & & & Similpal & Odisha & Elephant & III & 846 & 1980 \\
\hline & & & Gir & Gujarat & Lion & IV & 1412 & 1965 \\
\hline & & & Kanha & MP & Tiger & IV & 940 & 1973 \\
\hline & & & Sundarban & WB & Tiger & $\mathrm{I}$ & 1330 & 1984 \\
\hline & & & $\begin{array}{l}\text { Namdapha } \\
\text { (Changlang) }\end{array}$ & Arunachal & Tiger, Leopard & IV & 1809 & 1983 \\
\hline & & & Bandipur & Karnataka & elephants & & 874 & 1974 \\
\hline & & & The great Himalayas & H.P. & Snow leopard & VI & 755 & 1962 \\
\hline & & & Kaziranga & Assam & rhinoceroses & & 860 & 1974 \\
\hline & & & Great Rann & Gujarat & & & 7055 & 2002 \\
\hline 2 & Marine NP & 1 & Gulf of Kutch & Gujarat & & & 873 & 1982 \\
\hline 3 & Forest reserve & 1 & Kohli Khera & Hariyana & & & 06 & 1975 \\
\hline 4 & \multirow{2}{*}{ Games reserve } & 2 & Lung Nag & $\mathrm{JK}$ & & $\mathrm{V}$ & 400 & \\
\hline & & & Gajneer & Gujarat & Blue Bulls & & 6.0 & \\
\hline
\end{tabular}

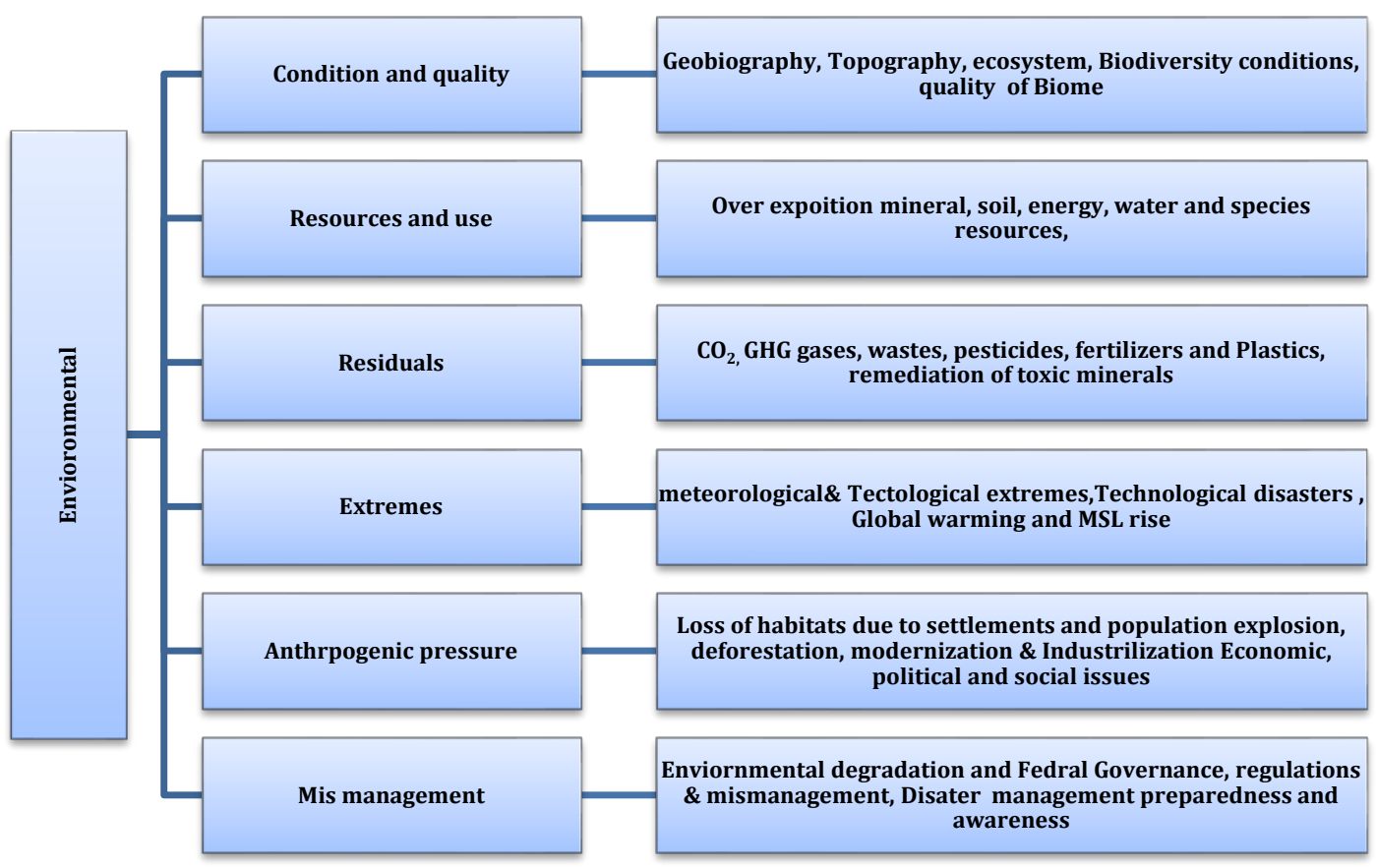

Fig 16: The causes/Framework for reverse gearing for biodiversity distortion in India 
Table 10: The RAMSAR Convention Sites in India, https://www.pmfias.com/ramsar-sites-india

\begin{tabular}{|c|c|c|c|c|c|c|c|}
\hline Sl No & Ramsar site & State & $\begin{array}{c}\text { Area } \\
\left(\mathrm{Km}^{2}\right)\end{array}$ & $\begin{array}{c}\text { Sl } \\
\text { No }\end{array}$ & Ramsar site & State & $\begin{array}{c}\text { Area } \\
\left(\mathrm{Km}^{2}\right)\end{array}$ \\
\hline 1 & Chilika lake & Odisha & 1165 & 15 & Koleru lake & $\mathrm{AP}$ & 901 \\
\hline 2 & Harike wetland & Punjab & 41 & 16 & Bhitarkanika & Odisha & 650 \\
\hline 3 & Keoladeo NP & Rajasthan & 28.7 & 17 & Tsomoriri & $\mathrm{J} \& \mathrm{~K}$ & \\
\hline 4 & Loktak lake & Manipur & 266 & 18 & Point Calimere & TN & 385 \\
\hline 5 & Sambar lake & Rajasthan & 240 & 19 & Sasthamkota Lake & Kerala & 3.73 \\
\hline 6 & Wular lake & $\mathrm{J} \& \mathrm{~K}$ & 189 & 20 & Bhoj Wet;land & MP & 32 \\
\hline 7 & Kanji lake & Punjab & 1.83 & 21 & Vembanad-Kol WL & Kerala & 1512 \\
\hline 8 & Ropar lake & Punjab & 13.65 & 22 & Hokera WL & $\mathrm{J} \& \mathrm{~K}$ & 13.75 \\
\hline 9 & East Kolkata WL & WB & 125 & 23 & Chandertal WL & $\mathrm{HP}$ & 0.49 \\
\hline 1 & Deepor Beel, & Assam & 40 & 24 & Renuka Wetland & $\mathrm{HP}$ & 0.20 \\
\hline 11 & Astamudi Lake, & Kerala & 614 & 25 & Rudrasagar Lake & Tripura & 2.4 \\
\hline 12 & Pong Dam Lake, & Himachal Pr. & 156 & 26 & $\begin{array}{c}\text { Upper Ganges R. Brijghat to } \\
\text { Narora }\end{array}$ & UP & 266 \\
\hline 13 & Deepor Beel, & Assam & 40 & 27 & $\begin{array}{l}\text { Nala Sarovar Bird } \\
\text { sanctuary (2012) }\end{array}$ & Gujarat & 123 \\
\hline 14 & Astamudi Lake, & Kerala & 614 & & WL- wetland & & \\
\hline
\end{tabular}

\section{Discussion}

India became a State Member of IUCN in 1969, through the Ministry of Environment, Forest and Climate Change (MoEFCC). About 15,000 flowering plants, 2546 numbers of fish species, 198 numbers of amphibians, 423 species of mammals, 408 numbers of reptiles and 1331 species of avifauna harbor in India. Out of all the habitats 33\% of species are endemic. Species like Nilgiri Tahr, Wild Ass, and the Lion-tailed Macaque of 44 taxa of species are in the endemic list of the country. IUCN had reported India had 47 species in 2011 and 132 species in 2012 (Rio summit) critically endangered in India. As per the WWF, India's report on 2018, there were $1,00,000$ Indian tigers during the early $20^{\text {th }}$ century whereas at present there are only 2,226 tigers left in India due to anthropogenic factors. The world has lost about $95 \%$ of its tiger's population as they need 25000 acres per tigers There are around 187 endemic reptiles, and 110 endemic amphibian species in India. Moreover the human species in form of tribal, aboriginal people of the Biogeographic region need to be preserved to sustain our ecosystem. http://india endangered. com/facts-you-did.

\section{Biodiversity Services}

The trifold services provided by the biodiversity of a region are ecological services, biological and social services. The ecosystem provisions are formation and purgation soil and water, climate stability, Nutrient storage whereas the biological services provided are as food, shelter, medicine, fuel, households, orchids, diversity of genes. The social services are cultural issues, research, education, monitoring of species statistics, recreation, tourism.

6.1.0 Indian federal policies for the preservation of species

The Preservation Acts are instituted and administered under the provisions of the Wild Life (Protection) Act,
1972, with subsequent amendments. The forest conservation acts constituted as Indian Forest Act, 1927 subsequently revised Forest (Conservation) Act, 1980, Environment (Protection) Act, 1986 and Biological Diversity Act, 2002 and the Scheduled Tribes and Other Traditional Forest Dwellers (Recognition of Forest Rights) Act, 2006. In order to strengthen wildlife conservation within inter-continent and interstate, India became a member of the Convention on International Trade in Endangered Species of Wild Fauna and Flora (CITES) in 1976, International Union for Conservation of Nature (IUCN) in 1983, International Convention for the Regulation of Whaling, UNESCO-World Heritage Committee and Convention on Migratory Species (CMS). The National Mission for Green India (GIM) is one of the eight Missions under the National Action Plan on Climate

Change (NAPCC) with the objective to protect; restore and enhance India's diminishing forest cover and retorting to climate change. It focuses on multiple ecosystem services, biodiversity, water, biomass, mangroves, wetlands, critical habitats with carbon sequestration as a co-benefit on PPC mode. The causes for biodiversity and framework for reverse gearing are in fig 16.

\subsubsection{The RAMSAR Sites India}

The RAMSAR convention has prepared an inventory of Wetlands of global importance for the protection and sustainable usage of wetlands, considering the economic, cultural, scientific, and recreational value of their stakeholders. India has 27 such sites whose details are given in Table 10. The RAMSAR convention constituted in 1971 provides "ecosystem services" which provides to the stake Holders of the wetlands from aspects of humanity, freshwater supply, food, habitation, and biodiversity, flood control, groundwater, and climate change. About $64 \%$ of the wetlands of the globe have disappeared in the last cen19th and $20^{\text {th }}$ century due to anthropogenic activities and climate change. 
In the present epoch, many a species and taxa's have been preserved in name of religion by the ethnic and the aboriginal people. The global protected areas network on land mass has grown significantly in the $21^{\text {st }}$ century. The MPN areas are neglected due to unplanned development work, fishery and projects like power plants and ports. Although all regions have extension in both their marine and terrestrial networks, the global marine area covered by protected areas is still very much under-represented. However, an increasing number of large marine protected areas have been designated over the last few years and it is hoped that this trend will continue so that there is a sufficient marine coverage to protect biodiversity. The Chilika Lake which was a RAMSAR site (Site No 221) was uplifted from Monteux record 2002 due to the overall development of the lagoon.

\section{Conclusion}

The last two decades of the 21st century have witnessed apocalyptic acts of nature, the dramatic changes in its biogeography, biodiversity, stratigraphy, mineralogy and the celestial doldrums to name it as the period "Golden Spikes or the great acceleration" in the novice Anthropocene epoch. Our biosphere is an aggregation of flora and fauna found in landmass, and oceans. The biodiversity contributes to variant genetic, species and ecosystem are due to biogeography, geomorphology, limnology and topography, of the area which is under the anthropogenic stress.

The makers of the epoch, the Home Sapiens have tried to catalog the number of extant species and the numbers threatened, and extinct. With a very small time series data it shows only the amphibians are the worst affected followed by the mammals by the erratic climatic changes under anthropogenic pressure.

Since time series record available is scanty, a clear study about the trend, vulnerability, extinction and model development as per the specific biogeography of the area shall be clear and productive. However present study reveals the amphibians, mammals are more susceptible to be threatened, vulnerable and extinct. The pollution, damming, IAS have threatened the endemic fish population. Since the kingdom of protists and microbiology has been less explored, needs to be stressed as they are the worst killers. The huge Oceania species kingdom on the earth should be the focused area of every biologists and data availability is scanty. The flora and fauna of the east coast of India, EGB Hills range are destroyed in the names of human progress which is one of the important migration paths of the Palearctic avifauna and the wild animals.

But the biodiversity has suffered irreversible damage due to anthropogenic activities like urbanization, deforestation, industrialization, tourism, mining and growth in population. Many of the species have become extinct, endangered and threatened 'and the gradual increase in their numbers may point to the fact that globe is probably heading towards sixth mass extinction in due course. The present activities of the modern man should be the reverse gear of the technology advancement.

\section{References}

Sclater P. L., 1858. On the general geographical distribution of the members of the class Aves. Zoological Journal of the Proceedings of the Linnean Society 2: 130-145.

Wallace A. R., 1876, The Geographical Distribution of Animals, Vol. I \& II.'(Harper and Brothers: N.Y.)

Wegener AL. 1915. Die Entstehung der Kontinente und Ozeane. Braunschweig: Vieweg. https://evolution. berkeley.edu/evolibrary/article/history_16

Wegner Alfred, 1929, The origin of continents and oceans, English edition translated from $4^{\text {th }}$ edition by John Biram, 1968, Methuen, London (1968).

Toledo Victor M., 2017, Indigenous peoples and biodiversity, Institute of Ecology, National University of Mexico (UNAM) In: Levin, S. et al., (eds.) Encyclopedia of Biodiversity. Academic Press (in press).pp 1-22, https://pdfs.semanticscholar.org/ 74a2/.

Rai R. and Nath V.,2003, The role of ethnic and indigenous people of India and their culture in the conservation of biodiversity, 0186-A1, Tropical Forest Research Institute, Jabalpur, Indian Council of Forestry Research and Education, Madhya Pradesh, India 482021. Email rajiv_rai_57@hotmail.com

Welsh, H.H.J. \& Ollivier, L. M., 1998, Stream Amphibians as Indicators of Ecosystem Stress: A Case Study from California's Redwoods. Ecological Applications Vol- 8 (4), pp-1118-1132.

Malhotra A. \& Thorpe, R.S., 1999, Reptiles and Amphibians of the Eastern Caribbean. London: Macmillan Education Ltd, pp- 20-51.

Sheridan C.D. \& Olson, D.H., 2003. Amphibian assemblages in zero-order basins in the Oregon Coast Range. Canadian Journal of Forest Research Vol-33, pp-1452-1477.

Ministry of Environment and Forests, India, 2010, Biodiversity, Envis News Letter, Centre for environmental studies,(CES), Vol. 21 (April - June -2010), MOEF, GOI

Vivero J. L, Kelbessa E. and Demissew S, 2005, The Red List of Endemic Trees \& Shrubs of Ethiopia and Eritrea, Fauna and Flora International, Global Trees Campaign, pp. 1-28, IUCN, DOI: 10.13140/2.1.3139.6168

Mani, M.S., 1976, Ecology and biogeography in India, W. Junk. The Hague.

Darlington PJ Jr (1957)'Zoogeography: the geographical distribution of animals.'(Wiley: New York)

Mishra S. P., 2018, Defaunation during Great Acceleration Period of Anthropocene Epoch: India, World Applied Sciences Journal, Vol. 36(3), pp. 506-518, DOI 10.5829/idosi.wasj. Jan-2018.

Mora C, Tittensor DP, Adl S, Simpson AGB, Worm B (2011) How Many Species Are There on Earth and in the Ocean? PLoS Biol 9(8): e1001127. https://doi.org/ 10.1371/journal.pbio.1001127

Holt, B. G., Lessard, J.P., Borregaard M. K., Fritz, S. A., Araújo, M. B., Dimitrov, D., Fabre, P.-H., Graham, C. H., et. al, (2013), An update of Wallace's zoogeographic regions of the world, Science, vol. 338, pp. 74-78

Khan T.I. , Dular A. K. and Solomon D. M., 2003, Biodiversity Conservation in the Thar Desert; with Emphasis on Endemic and Medicinal Plants, The Environmentalist, Springer, Vol. 23(137), https://doi.org/10.1023/ A:1024835721316 
Wafer M., Wafer S., David J. J., 1990, Nitrification in reef corals, Limnology and Oceanography, pp-35

DOD \& SAC .1997. "Coral reef maps of India," Department of Ocean Development and

Space Application Centre, Ahmedabad, India

Jyoti S., Gautam R. Ku. Joshi A. and Tehseen ., 2016, Review of coral reefs of India: distribution, status, research and management, International Journal of Science, Environment ISSN 2278-3687 (0), Vol. 5, No 5, PP- 3088 3098.

Rajan, R., Jeyabaskaran, R., Venkataraman, K., (2011) Indian Coral Reefs: Functions, threats and management issues' In: Marine Biodiversity in India, S. Kannaiyan \& K. Venkataraman (eds.) Published by: Associated Publishing Co., New Delhi, India.

Jayaprakas V. \& Radhakrishnan R., 2014, Indian coral reefs: diversity, anthropogenic influences and conservation measures, International Journal of Humanities, Arts, Medicine and SciencesVol. 2,(4), PP- 25-36, Philipose K.K., Artificial Reefs,

Pillai, C.S.G. (1996) "Coral reefs of India: Their Conservation and Management, in (Pillai CSG and Menon N.G. eds) "Marine Biodiversity, Conservation and Management," CMFRI, Cochin, India. Pillai, C.S.G., Jasmine, S. 1989. The coral fauna. Central Marine Fisheries Research Institute Bulletin 43: 179- 194.

Dey Kalyan,, Mote S., Tsering L, Perisamy R, Patil V., Nagesh R.,. Hussain A, et al.,2015, biodiversity and status of Coral Reef in MalvanMarine Sanctuary, Central West Coast of India, Conference: 4th National Conference of Ocean Society of India (OSICON 2015), Goa, 22-24, Conference: 4 th National Conference of Ocean Society of India (OSICON 2015), Goa, 22-24

Krishnamurthy, K. 1987. "The Gulf of Mannar Biosphere Reserve: Project document-5, Ministry of Environment \& Forests, Government of India.

Pillai, C.S.G. and Jasmine, S. 1989. The coral Fauna of Lakshadweep. Bull 43, CMFRI, Cochin, India.

SAC. 2010. Coral Reef Atlas of the World, Central Indian Ocean. Space Application Centre, Indian Space Research Organization, Ahmedabad, India. 1: 281.

Darwin Charles, 1859, The origin of species by means of natural selection or the preservation of favored races in the struggle for life, London, John Murray.

Ali A. H., 1949, Some peculiarities of avifaunal distribution in peninsular India. Proceedings of the National Academy of Sciences, vol. 15 (8): pp-387-393

Hora S. L., 1949. Satpura hypothesis of the distribution of Malayan fauna and flora of peninsular India. Proceedings of the National Institute of Science of India Vol-15: pp309-314

Ripley, S. D. 1978. Changes in the bird fauna in a forest area, Simlipal hills, Mayurbhanj district and Dhenkanal district, Orissa. J. Bombay Nat. Hist.., 75:570-574

Karanth, K. P,. 2003. Evolution of disjunct distribution among wet zone species of the Indian subcontinent: Testing various hypothesis using a phylogenetic approach. Current Science Vol- 85(9), PP- 101-108

Mani, M.S. 1974. Biogeographical evolution in India. In Ecology and Biogeography in India (ed.) M.S. Mani. W. Junk, Hague, pp. 698-724.

Shukla R. P., 2006, Biogeography and vegetation types of India, DDU Gorakhpur University.

Medlicott H. B., Blanford W. T., 1879. Manual of the geology of India. Calcutta: Geological Survey of India, 445-817

Wegener A,1966, The Origin of Continents and Oceans, 4th edition, translated by John Biram, Dover Publications Inc., New York

MacArthur, R. H., Wilson E. O.. 1963, An equilibrium theory of insular zoogeography, Evolution Vol-17 PP-373-387.
MacArthur, R. H., Wilson E. O., 1967, The theory of island biogeography. Princeton University Press.

Dilger W C 1952 The Brij Hypothesis as an explanation for the tropical faunal similarities between the Western Ghats and the eastern Himalayas, Assam, Burma, and Malaya; Evolution 40 977-996

Fuller M. R., Millspaugh J. J., Church K. K., Kenward R.E., Bookhout T. A.,2005, Wildlife radio telemetry, research and management techniques for wildlife and habitats, 2005Bethesda, MD, The Wildlife Society, PP- 377-417

Hobson K. A., Wassenaar L. I., 2008, Tracking animal migration with stable isotopes. Volume 2, Terrestrial Ecology Series, San Diego Academic Press

Holland R. A., Wikelski M., 2009, Studying the migratory behavior of individual bats: current techniques and future directions, J Mammal, Vol- 90, pp- 1324-1329

IUCN., IUCN Red List Categories and Criteria. Switzerland and Cambridge, UK: IUCN; 2018. Version 3•1 IUCN Species Survival Commission. Gland.

Deguignet M., Juffe-Bignoli D., Harrison J., MacSharry B., Burgess N., Kingston N., (2014) 2014 United Nations List of Protected Areas. UNEP-WCMC: Cambridge, UK.

UNEP-WCMC (2018). Protected Area Profile for India from the World Database of Protected Areas, July 2018. Available at: www.protectedplanet.net

Ministry of Statistics \& Programme Implementation, 2015, Compendium Government of India, 2015, Ministry of Statistics \& Programme Implementation, Central Statistics Office, Social Statistics Division, New Delhi, www.mospi.gov.in, PP- 26

Wafar, M., Venkataraman, K., Ingole, B., Ajmal K.S. \&, LokaBharathi, P. (2011) State of knowledge of coastal and marine of Indian Ocean countries. PLOS One, 6(1), e14613.

Venkatratnam K., Wafar M., 2005, Coastal and marine biodiversity of India, Indian Journal of Marine Sciences, Vol 34(1), pp. 57-75

UNEP-WCMC and IUCN (2018) Marine Protected Planet [Online], [July, 2018], Cambridge, UK: UNEP-WCMC and IUCN Available at: www.protectedplanet.net.

Mishra S. P., 2017, The apocalyptic Anthropocene epoch and its management in India, Int. Jour. Adv. Research, Vol. 5(3), pp. 645-663

Chatterjee, D., 1962, Floristic patterns of Indian Vegetation, Proa Sum. Sch Bot Darjeeling, PP- 32 - 42.

FAO, Scherf D., 2000, World watch list, for domestic animal diversity, (WWL-DAD:3) $3^{\text {rd }}$ edition, the Food and Agriculture Organization of the United Nations, pp1-746

Ministry of Statistics \& Programme Implementation, 2015, Compendium Government of India, 2015, Ministry of Statistics \& Programme Implementation, Central Statistics Office, Social Statistics Division, New Delhi, www.mospi.gov.in, PP- 26

The government of India, 2017, New breeds registered, ICARNational Bureau of Animal Genetic Resources

(NBAGR)(ISO http://www.nbagr.res.in/registeredbreed.html

9001:2008

Das B. Ch., Das J. K., 2016, Livestock Biodiversity of Odisha, Govt of Odisha, Odisha review, May-June 2016

Balakrishnan, N. P., 1996, Phytogeographic Divisions: General Considerations. In: P. K. Hajra et al. (eds.). Flora of India, Introductory Volume (Part I): Pp. 197 - 204.

Nayar M. P. 1996, Hotspots of endemic plants of India, Nepal and Bhutan. TBGRI, Thiru vananthapuram.

Mishra D. P., Mishra S. P., Mishra N. K., Sahu M., 2018, Management of Declining Soymeal exports from India, Int Journal of Advanced Research, Vol- 6(5), pp-48-65, DOI: 10.21474/IJAR01/7007

Arisdason W., Lakshminarasimhan P.,2017, the status of plant diversity in India: an overview, ENVIS Centre on Floral Diversity, MOEF, GOI, http://www.bsienvis.nic.in 